\title{
A Holistic Review of the Present and Future Drivers of the Renewable Energy Mix in Maharashtra, State of India
}

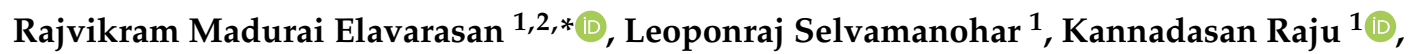 \\ Raghavendra Rajan Vijayaraghavan ${ }^{3}$, Ramkumar Subburaj ${ }^{1}$, Mohammad Nurunnabi ${ }^{4}$ (D), \\ Irfan Ahmad Khan ${ }^{5}{ }^{\oplus}$, Syed Afridhis ${ }^{6}$, Akshaya Hariharan ${ }^{1}$, Rishi Pugazhendhi ${ }^{6}$, \\ Umashankar Subramaniam ${ }^{7}\left(\right.$ i) and Narottam Das ${ }^{8,9}$ (i)
}

1 Department of Electrical and Electronics Engineering, Sri Venkateswara College of Engineering, Chennai 602117, India; leoponraj98@gmail.com (L.S.); kannadasanr@svce.ac.in (K.R.); ramjey123@gmail.com (R.S.); hakshaya.11@gmail.com (A.H.)

2 Electrical and Automotive parts Manufacturing Unit, AA Industries, Chennai 600123, India

3 Research and Development Laboratory, Innovate Educational Institute, Chennai 600069, India; raghuraghavan89@gmail.com

4 Business Society and Environmental Laboratory, College of Business Administration, Prince Sultan University, Riyadh 11586, Saudi Arabia; mnurunnabi@psu.edu.sa

5 Marine Engineering Technology Department in a Joint Appointment with Electrical and Computer Engineering, Texas A \& M University, Galveston, TX 77553, USA; irfankhan@tamu.edu

6 Department of Mechanical Engineering, Sri Venkateswara College of Engineering, Chennai 602117, India; syedafridhis2000.sa@gmail.com (S.A.); rishi2000.p@gmail.com (R.P.)

7 Renewable Energy Laboratory, Prince Sultan University, Riyadh 11586, Saudi Arabia; shankarums@gmail.com

8 School of Engineering and Technology, Central Queensland University, Melbourne 3000, Australia; n.das@cqu.edu.au

9 Centre for Intelligent Systems, School of Engineering and Technology, Central Queensland University, Brisbane 4000, Australia

* Correspondence: rajvikram787@gmail.com

Received: 1 July 2020; Accepted: 4 August 2020; Published: 14 August 2020

\begin{abstract}
A strong energy mix of Renewable Energy Sources (RESs) is needed for sustainable development in the electricity sector. India stands as one of the fastest developing countries in terms of RES production. In this framework, the main objective of this review is to critically scrutinize the Maharashtra state energy landscape to discover the gaps, barriers, and challenges therein and to provide recommendations and suggestions for attaining the RES target by 2022. This work begins with a discussion about the RES trends in various developing countries. Subsequently, it scrutinizes the installed capacity of India, reporting that Maharashtra state holds a considerable stake in the Indian energy mix. A further examination of the state energy mix is carried out by comparing the current and future targets of the state action plan. It is found that the installed capacity of RESs accounts for about $22 \%$ of the state energy mix. Moreover, the current installed capacity trend is markedly different from the goals set out in the action plan of the state. Notably, the installed capacity of solar energy is four times less than the target for 2020. Importantly, meeting the targeted RES capacity for 2022 presents a great challenge to the state. Considering this, an analysis of the state's strengths, barriers, and challenges is presented. Moreover, strong suggestions and recommendations are provided to clear the track to reach the desired destination. This can be useful for the government agencies, research community, private investors, policymakers, and stakeholders involved in building a sustainable energy system for the future.
\end{abstract}


Keywords: Maharashtra Energy System; energy mix; energy policy; Renewable Energy Sources; sustainability

\section{Introduction}

Various renewable energy sources such as solar, wind, biomass, hydro, and waves are utilized around the world in developing the renewable energy sector [1]. Due to fluctuations in oil prices, many countries are pressured to shift toward environmentally friendly renewable technology with fixed prices [2]. Overall, 19\% of the total energy demand was met by the renewable energy sector in 2015 [3,4]. As of November 2019, 195 members of the United Nations Framework of Climate Change (UNFCCC) signed an agreement to implement renewables [5]. To reduce the effect of carbon dioxide $\left(\mathrm{CO}_{2}\right)$ emissions on climatic conditions, the UNFCC suggested installing renewables and reducing per capita consumption [6]. It is recognized that the transition to renewable energy leads to resilience, transforms essential processes, and represents a strong approach to consumption and production [7]. Although Renewable Energy Sources (RESs) have relatively high installation costs, their running costs are low [8]. Since 1990, the Organization for Economic Co-operation and Development has increased their production of renewable energy by $2.3 \%$, while other countries have increased their production by $4.5 \%$ [9]. Renewable energy production was seen to increase in many countries with a decrease in renewable energy production costs [10]. Moreover, in comparison to conventional energy production, renewable energy production was seen to reduce greenhouse gas emissions due to its efficient utilization of resources [11,12].

Cicea and Marinescu [13] explained the advantages of renewable energy over conventional energy by considering various factors. Other works have analyzed the importance of renewable energy in improving the environment and obtaining energy sustainability [14,15]. In addition, studies have revealed that the Nordic countries—namely, Finland, Sweden, Norway, Denmark, and Iceland-are enhancing their utilization of renewable energy resources [16,17]. The European Commission supports and promotes the utilization of renewable energy sources [18]. With the year 2050 as a target, many countries are aiming for net-zero emissions of greenhouse gases [19]. Over the years, the energy sector has shown interest in the use of renewable energy resources by minimizing the use of fossil fuels to meet energy demand. Recently, various Association of Southeast Asian Nations (ASEAN) countries have made efforts to use renewable energy to overcome the drawbacks of fossil fuels [20,21]. In fact, the governments of many nations have decided to reduce the use of carbon and increase the use of renewables to ensure sustainable global development [22]. The United Nations (UN) released 17 Sustainable Development Goals (SDGs) in 2015 [23]. The UN, national governments, civil society, research community, policymakers, private sector, and stakeholders are working together toward the growth of sustainable energy systems [24]. Much ongoing research pertains to the fulfilment of SDG 7 [25]. Various countries adhere to the SDGs by forming cooperative structures that enable them to attain their individual targets for renewable energy production [26].

India is one of the largest countries on the Asian continent. In terms of population, it is the second-largest country after China. Because of its increasing population, the demand for energy has also increased rapidly. In 1992, the Indian Ministry of Non-conventional Energy Sources was founded; this ministry was renamed in 2006 and is now known as the Ministry of New and Renewable Energy (MNRE) [27]. In India, energy is produced from both conventional and non-conventional resources. Due to the power crisis, countries like India are facing economic demand [28]. As conventional energy resources will be exhausted in the upcoming years, India is showing more interest in the development of renewable energy. India needs to improve its utilization of renewable energy sources. As such, the government has decided to implement policies promoting environmentally friendly and renewable energy resources [29]. Apart from the policies, it is also important to raise awareness raise awareness in the society to know the importance of renewable energy resources [30,31]. 
The reasons for installing renewable energy resources are to address the crisis of conventional environmental pollution and to raise the economic growth of the country. The challenge for India is to deal with the climatic conditions and develop renewable energy resources according to policymakers [32,33]. Millions are facing shortages of electricity in the nation, which has made India realize the importance of renewable energy resources [34,35]. By 2027, India aims to reach $44.4 \%$ renewable energy sources [36]. There are two important tools-Feed-In Tariffs (FITs) and Renewable Purchase Obligations (RPOs). FITs allow the injection of power into the grid for tariffs, and RPOs are obligations to buy specific renewable energy resources [37]. A decentralized distribution generation scheme verified that many remote villages could provide renewable energy resources, mainly home solar systems $[38,39]$. The government agreed to pay part of the FITs for renewable energy resources for the next 20 to 25 years [40,41]. A figure of merit was developed to find the level of usage of renewable energy sources across the nation [42]. Linear programming was formulated to determine the availability of land and geographic areas to meet peak power demands [43]. An optimization model was developed to allocate renewable resources to various users by 2020-2021 [44].

Renewable energy resources accounted for $20 \%$ of the total installed capacity, which was approximately $71.325 \mathrm{GW}$ as of 31 March 2018, and the target is to attain 175 GW of renewable energy by $2022[45,46]$. In connection with this, various methodologies and approaches are adopted by researchers to enhance RES technologies. In order to evaluate renewable energy technologies in India, Rani et al. developed a new method using the novel divergence and entropy measures of Pythagorean fuzzy sets (PFSs) and the Vlsekriterijumska Optimizacija I Kompromisno Resenje (VIKOR; in English, multicriteria optimization and compromise solution) and reported that PF-VIKOR was effective for selecting and evaluating RE technologies [47]. Further, based on new divergence measures for RES selection, a novel approach was adopted using extended fuzzy Technique of Order Preference Similarity to the Ideal Solution (TOPSIS) [48]. To aggregate decisionmakers' preferences, criteria weights are determined using theInterval-Valued Probabilistic Linguistic Standard Variance (IVPLSV) approach, and alternatives are ranked using the extended VIKOR method in an IVPLTS environment [49]. For economic strategy analysis in India, Dynamic Ordinary Least Squares (DOLS) estimation was adopted by researchers. The observed results suggested statistically significant and positive impacts of economic growth and financial development on RE consumption [50].

In order to study the progress of RESs in India, the state of Maharashtra is considered. Maharashtra is an important state that is fully focused on installing renewable energy systems. As of 31 March 2018, the total equipped quantity of large hydro energy reserves was about 45.29 GW in Maharashtra. This state separates the country into two parts: North India and South India. The state is well known by its capital city, Mumbai, one of the country's metropolitan cities. It is the third-largest state and is surrounded by the Gujarat, Madhya Pradesh, Chhattisgarh, and Karnataka states. Due to its population, it has many energy consumers who create a strong demand for energy. Yet, this state contributes about $13.89 \%$ of India's overall power demand.

Being aware of renewable energy, the government of Maharashtra has taken several initiatives to develop energy production through renewable energy sources. The government established the Maharashtra Energy Development Agency (MEDA) to promote the advancement of non-conventional energy. The MEDA carried out several efforts to concentrate non-conventional energy in non-urban areas. At present, the overall equipped non-conventional energy of the state is approximately $6145 \mathrm{MW}$. The state has a non-renewable energy capacity of 24,105 MW [51]. Non-conventional energy has a $15.9 \%$ share in the overall power production of the state, with wind energy being effective, along with the co-generation of solar and small hydro. Various self-operational and hybrid non-conventional energy resources have been developed in Maharashtra to promote non-conventional energy utilization [52].

Hence, the main purpose of this work comprises the following:

- To give an understanding of the renewable energy scenario and performance in Maharashtra in terms of its use of renewable energy resources for the development of the state socially and economically. 
- To present research that has been carried out based on India's renewable energy scenario, policies, and initiatives and examine these studies by discussing their analysis in terms of meeting the needs of the renewable energy system of Maharashtra. A framework is designed for Maharashtra to identify suitable policies, journal publications, and work-related projects.

- To discuss various limitations and barriers and propose unique guidelines for future researchers to overcome the barriers in order to meet the needs of renewable energy resources in the state.

For precise knowledge of the novelty, constraints, and schemes established across different countries, the literature is presented and discussed in the following section.

\section{Methods for Survey Criteria}

This study focused on a particular state of renewable energy resource development. In order to get accurate data, the survey was carried out in two portions: the categorization of subjects and the analysis of the contents. All the real-time data were accessed online from official websites between March 2019 and May 2020.

In the first step, various sections of this review paper were considered. There were many criteria for including sections, but the necessary sections were selected and categorized as follows:

- Literature survey on non-conventional energy utilization by various countries;

- Technological advancements and policy schemes of various countries in the literature;

- Non-conventional energy status and technological development in India;

- Renewable energy scenario of Maharashtra: a case study;

- Upcoming green energy projects;

- Analysis of the RES potential of Maharashtra;

- Research outcomes and prospects of Maharashtra.

In the second step, the data for each category were analyzed. Though more data were obtained, only the useful data are presented. The data were narrowed down based on several factors, such as the date they were uploaded and the authority of the journal or website from which they were obtained. For this purpose, most of the real-time data were retrieved in March 2019 from official government websites, such as mahaurja.com and mnre.gov.in. Apart from the official websites, data were retrieved from reputed journals. The framework for this work is shown in Figure 1.

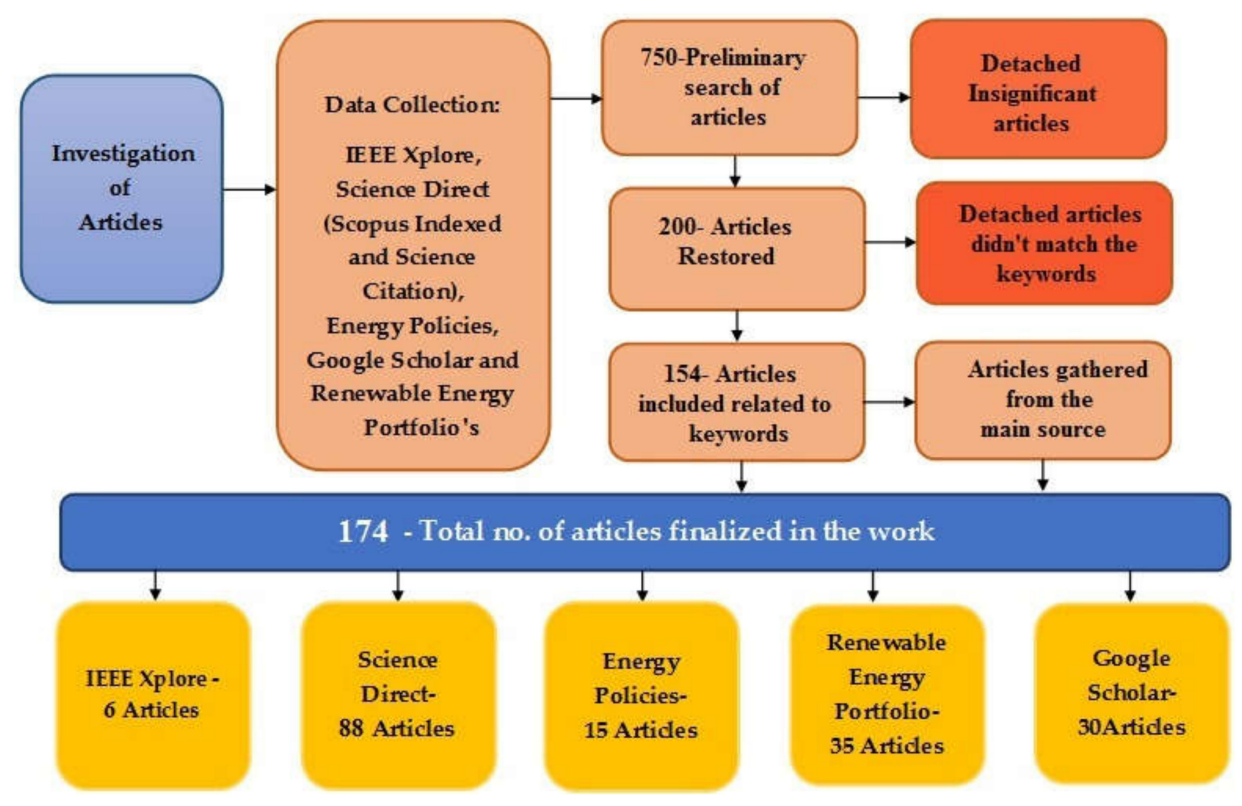

Figure 1. Framework of the proposed research work. 
A great deal of data were collected by the authors to build this proposed research work. The framework for the proposed work is as follows:

Initially, we collected articles related to renewable energy development in various developed and developing countries in the world. Later, we concentrated on India's RES. Further, the renewable energy status of Maharashtra is elaborated on in this work to prove the effectiveness of renewable energy systems in the state. Through the framework, 750 articles were considered in the preliminary search, and insignificant articles were separated by setting aside 200 articles for further review. The framework process was conducted by utilizing keywords of the proposed work, yielding 154 articles. We also gathered articles from important sources by analyzing the major areas. In total, 174 articles were cited.

\section{Non-Conventional Energy Utilization by Various Countries}

Non-conventional energy systems are developed to avoid the constraints imposed by weather conditions, and resources can be used by various sources for long periods without any disturbances $[53,54]$. Hybrid non-conventional energy resources are developed in Australia, which involves modeling, techno-economic analysis, and load managing [27]. In one study, there were no restrictions based on daily schedules for hybrid non-conventional resources, and they worked for the whole day without any intervals [55]. In various studies, researchers have developed various controller models for the hourly distribution of non-conventional energy in daily life [56]. In particular, studies were conducted using parameters such as economic, environmental, and reversion for solar photovoltaic (PV), wind, and grid supply energy systems. The energy usage through solar cooling in the Nordic countries was also estimated $[57,58]$. The combination of solar plants and co-generation plants was also examined. In India, off-grid power production was designed, and it has seen a huge reduction in part of the cost [59]. The mix of renewable energy sources was studied to satisfy the needs off-grid production with stable operation [60,61]. In India, many non-urban areas are still facing energy demands and shortages, which could be solved using hybrid non-conventional energy production in a commercial way. An integrated renewable energy optimization model was used to provide electricity for villages through an integrated system [62,63]. In order to help achieve a pollution-free environment, researchers adopted a combined dispatch strategy, where a hybrid renewable energy system based on lithium ion batteries delivered optimal operational costs [64]. With a hybrid (PV-wind) system, it was found that there was a reduction of $\mathrm{CO}_{2}$ emissions by nearly $70 \%$ to $80 \%$ [65]. The growth in solar energy across various countries from 2013 to 2019 is presented in Figure 2. It is observed that the generation of solar energy has been increasing from 2017. India also stands as a fast-developing country in terms of solar energy; its rate of growth increased considerably between 2017 and 2019.

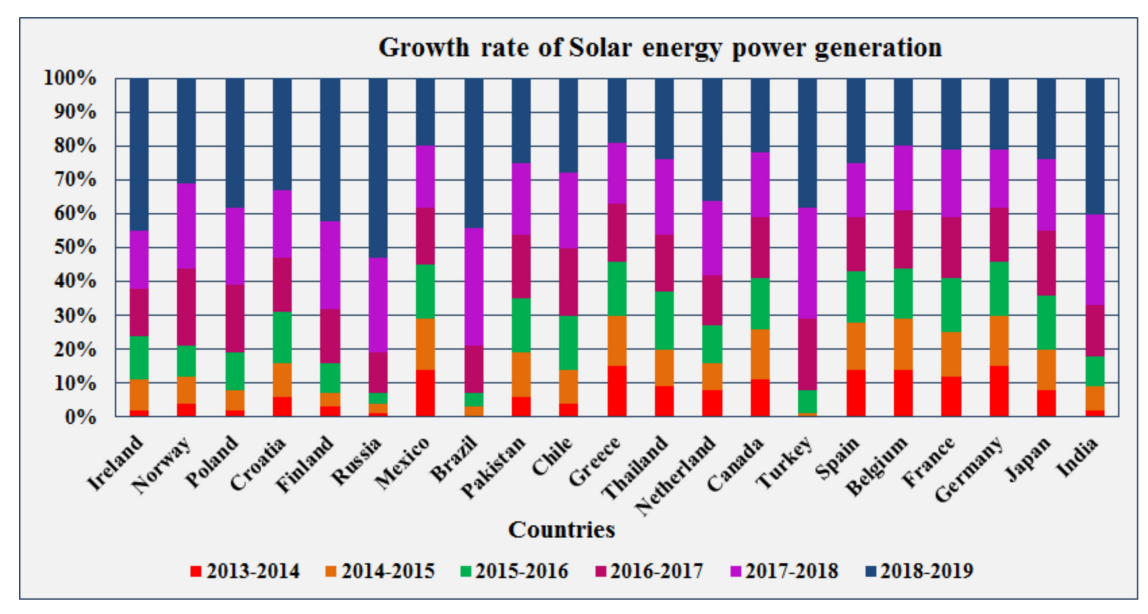

Figure 2. Growth rate of solar energy in different countries. 
The growth rate of wind energy has been increasing across various countries in the world. The trend of the growth rate over the last seven years is presented in Figure 3, where India also stands as a fast-developing country in terms of wind energy, particularly in 2017-2019.

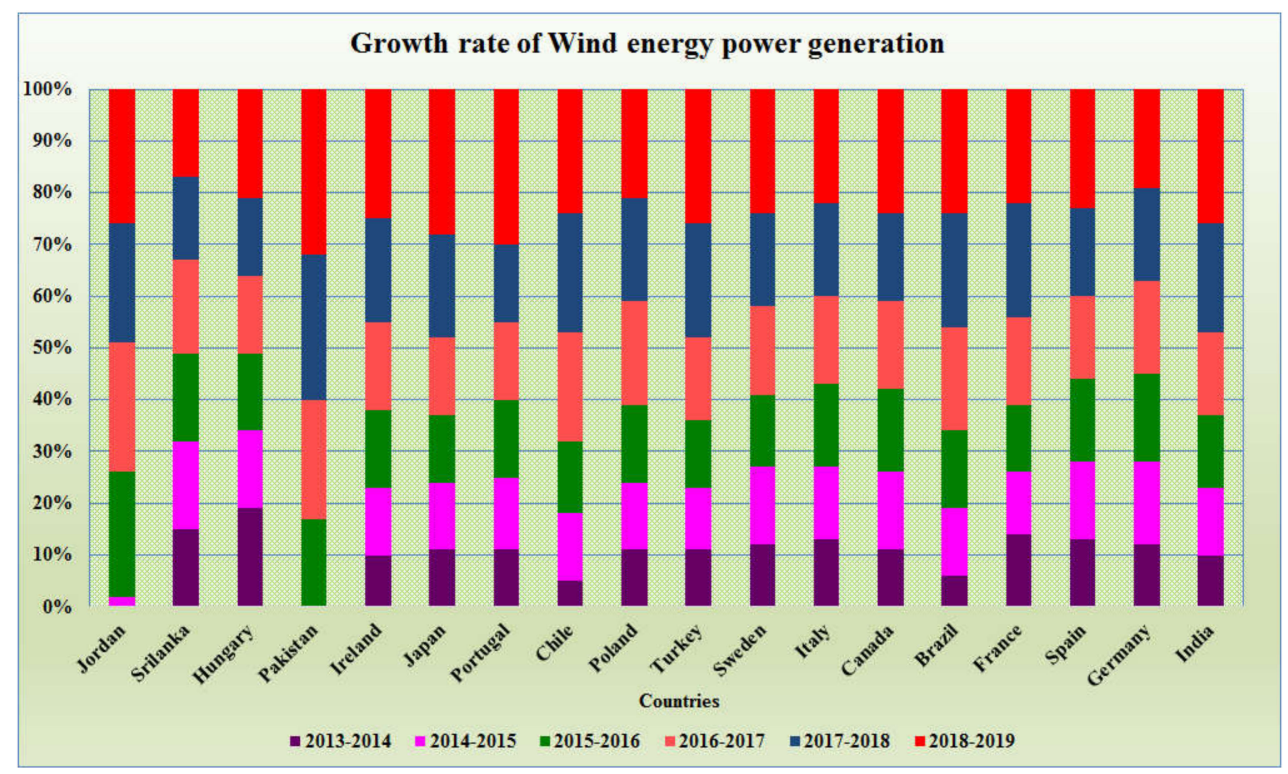

Figure 3. Growth rate of wind energy in different countries.

The policies adopted by countries to develop renewable energy systems and their technological advancements are discussed in Section 3.1.

\subsection{Research Activities on RES}

This section clearly elucidates the various research activities on RES, and some of the significant research in a few countries pertaining to renewable energy is highlighted. Solar energy is considered as an alternative renewable energy source in many countries to overcome the energy crisis while lagging in energy production [66]. Recently, studies in Spain have been focused on solar energy and analyzed the cost of a large grid-connected photovoltaic (PV) system, which is low as it is static. Moreover, approximately $0.5 \%$ is utilized in capital investment for maintenance. Particularly, after 2005, there was a huge rise in the demand for PV systems in developing countries [67].

Primarily, researchers focused on the impact of electricity production on commercial development, since not all the electricity produced is consumed because of distribution losses and theft [68]. Hence, it is important to examine the effect of electricity production on development in real-time applications. Additionally, the research divides the sources for energy generation into renewable and non-renewable sources because of their lower cost and technological advancements. Non-renewable sources have gained importance in the energy sector and will soon be an alternative to fossil fuels. The study deviates from other studies, as it couples energy generation and gross domestic product (GDP) growth. One of the primary energy-based strength factors of a country is effective energy management. Research activities were carried out where energy management was also controlled by utilizing technologies such as Python and Internet of Things for hybrid systems in renewable energy [69].

A recent advanced study focused on renewable energy that can be used as a source for powering Eastern African countries toward industrialization and urbanization [70]. It is estimated that the output elasticity of non-renewable energy $(0.29-0.48)$ is greater than that of renewable energy $(-0.12$ to 0.08 ). However, technological developments and innovations are mostly based on non-renewable energy. Further, it is found that positive elasticity (0.77-0.92) contributes greatly to the transition 
toward renewable energy. Hence, it is proved that renewable sources should be considered in the development of industrialization in Eastern African countries.

Presently, investigations are focusing on energy resources (renewable or nuclear) to mitigate carbon emissions for 30 countries that benefitted from nuclear energy from 1990 to 2014 [71]. They studied the long-term relationship between carbon emissions and renewable and nuclear energy consumption. The tests proved that the nuclear energy does not contribute to carbon mitigation, unlike renewable energy consumption. Thus, it is proved that the advancement of renewable technologies has a greater impact on the economy than nuclear technologies.

Further, the link between the renewable and non-renewable energy production and international trade of 15 European Union (EU) countries are analyzed. Additionally, the dynamic relationship between output, renewable and non-renewable energy production, international trade, capital, and labor over the period of 1980-2015 is studied [72]. It is shown that the relative influence of renewable and non-renewable energy inputs varies greatly with the output levels in various countries.

Recent researchers examined the $\mathrm{CO}_{2}$ emissions, energy consumption, and commercial development in the Gulf Cooperation Cycle (GCC) countries [73]. The study was carried out with the help of annual time series data and an auto-regressive distributed lag (ARDL) model. The results revealed that there were long-run and causal relationships between carbon emissions and commercial development in GCC countries, except for the United Arab Emirates (UAE). This shows that financial systems must consider environmental conditions in their current operations in these countries.

Studies also focus on the influence of unconventional gas growth on China's natural gas generation and imports [74]. Due to the rapid increase in the consumption of natural gas, China had become a net importer of it. It is expected that a production peak will take place in conventional natural gas soon. The country has a rich source of unconventional natural gas reserves that have not been fully explored yet. The quest for low-carbon development, natural gas supply, and price reform has driven the country to opt for unconventional natural gas as an alternative. The results of the study revealed that exploiting China's unconventional natural gas reserve could highly advance the country's natural gas production.

Overall, 70\% of energy utilization was done by industries through conventional means in the past decade by China [74]. By 2020, China has planned to reduce the use of carbon and other fossil fuels.

Furthermore, an investment was made in installing solar ponds due to the abundant supply of water, sun, and land area in Turkey. Approximately $15-20 \%$ is invested in installing solar ponds [75].

Additionally, researchers examined whether non-renewable energy prices influence the volatility of renewable energy prices [76] by considering wooden pellets as their reference. It was observed that the southeastern US has had rapid expansion of wood-pellet biomass generation for European export over the past decade. This suggests that there are possible price volatility spillovers between renewable and non-renewable markets. Moreover, a BEKK-MGARCH (Multivariate Generalized Auto Regressive Conditional Heteroscedasticity) model was employed to study the effect, and the results show that there is a limited negative effect of past and volatile non-renewable energy price influencing the current wood pellet price volatility.

Shark El-Ouinat is a city in Egypt with a large wind turbine plant. Overall, 60 Fuhrlaander FL2500-104 wind turbines are installed in the city for $150 \mathrm{MW}$. There is an annual gain of $730,791 \mathrm{MWh} /$ year, with a high capacity of 56\% [77]. Nigeria has recently shown interest in developing solar energy generation to satisfy the power demand [78]. Similarly, other countries are focusing on generating power from solar energy [79-81] and wind energy [82] to meet their demand. Concentrated solar power (CSP) reached $4926 \mathrm{MW}$ in 2016. Additionally, Nigeria used a wind-powered water system to meet the water requirements across three divisional areas in Oyo state [83]. Perovskite solar cells showed a better efficiency compared to a silicon solar model and has a low price, and the panel works effectively even under low temperatures [84].

Many ongoing studies are consistently being carried out by researchers from India. Particularly, the efficient operation of PV panels was tested from various perspectives, including simulation- and 
experimentation-based investigations. The various topology connections of PV panels were tested under shading conditions, and it was observed that the bridge-linked honeycomb was a suitable topology for efficient operation [85]. Premkumar et al. tested various modern maximum power point tracking (MPPT) techniques to find a suitable one by implementing it on PV panels to improve the tracking efficiency under partial shading conditions [86]. Additionally, new metaphor-less algorithms, Rao-2 (R-II) and Rao-3 (R-III), are proposed in [87] to estimate PV cell parameters. In hybrid (PV-wind) RES, the sliding mode controlled MPPT algorithm is implemented for the photovoltaics to efficiently track and boost the output power, whereas in wind turbines a permanent magnet synchronous generator (PMSG) is utilized because of its lower weight, absence of a gear box, and lower maintenance cost [88]. Additionally, researchers explored how social initiatives function in rural India with decentralized RE solutions to access government assistance, and presented strategies to engage with the government using an inductive theory-building approach [89]. Further, an optimal techno-economic plan for an off-grid hybrid RES was discussed using metaheuristic optimization techniques for the application of radio transmitter stations in India [90].

Enhancing the efficiency of photovoltaics is an emerging area to explore at present. In the southern part of India, Rajvikram et al. conducted an investigation by implementing cooling methodologies using phase change materials (OM 29 embedded with aluminum sheet [91,92] and HS 29 embedded with finned heatsink [93]) toward the back surface of the photovoltaic panels. These investigations were carried out with the goal of enhancing the photovoltaic efficiency. Anti-reflective coating (ARC) technology was adopted on the PV, which is also an emerging technique [94]; some ARC materials such as $\mathrm{Al}_{2} \mathrm{O}_{3}$ and $\mathrm{Ta}_{2} \mathrm{O}_{5}$ [95] and $\mathrm{ZnS}$ and $\mathrm{SiO}_{2}$ [96] were studied and experimented on to determine the efficiency of the photovoltaics.

\subsection{Policy Schemes}

Several research works in China are effectively developing non-conventional energy resources. The economics, tariffs, work designs, and policies are being examined, and there are certain aspects that benefit non-conventional energy distribution [97,98]. Biomass is also considered as a major renewable energy source, with the conversion and processing of solid, liquid, and gaseous waste [99]. The significance of policy is more focused if it is not hard to obtain the target and vision of non-conventional energy for transportation [100]. In India, for specific regions (rural areas) researchers are developing models for renewable energy systems to avoid voltage fluctuations [101]. After being installed, a renewable energy system does not need regular maintenance and repairs [102].

Policies and government plans are more important in raising the public awareness of new technologies than in distributing non-conventional energy resources [103]. Intermittent sources such as wind and solar are the main ones to reduce emissions of greenhouse gases [104], and these will be reliable for operating smart energy systems (SESs) [105]. To access the potential and government policy frameworks, financial analyses and advantages are reviewed through the "footprint" approach by European countries [106]. Schemes such as FIT have been promoted to develop the use of renewable energy sources [107]. The European Union has set goals to increase the share of Renewable Energy Sources for Electricity (RES-E) [108].

In the UK, the banding policy led to an increase in consumer tariffs or more $\mathrm{CO}_{2}$ emissions and promoted innovative technologies for non-conventional energy sources [109]. There was a boost in government efforts to endorse the use of renewable energy to improve energy efficiency in Malaysia. An aggregated preferences index system is used to check the utilization of solar, wind, and biomass energy [110]. There is a prospect of saving surplus non-conventional energy, as the carbon-storing cycle depends on the awareness of the storing technique [111]. A major barrier to the widespread implementation of solar technologies is the inadequacy of storage systems to overcome intermittencies [112,113].

The diverse tariff-efficient plans are examined from the India framework. Carbon dioxide discharge from coal power plants has already led to catastrophic consequences [114]. It is necessary 
to take a risk in decreasing greenhouse gas emissions in order to promote healthy and continuous advancements in India [115,116]. This shows the status of renewable energy systems and technological advancements in the country. The enhancement in the renewable energy system of India is briefly explained in Section 4.

\section{Non-Conventional Energy Status and Technological Development in India}

In terms of non-conventional energy, India is the leading country in comparison with other countries such as China and the United States. After China, India is the only country that has a population of more than 1.3 billion. The population growth rate in India is $1.10 \%$ compared with China, which is at $0.39 \%$. India has always provided strong pathways for significant technologies pertaining to RE implementation and has acknowledged that renewable energy production should be a major contribution to survival [117]. Researchers have reported that these three countries could contribute two-thirds of the clean energy expansion by 2022 [118]. The growth of non-conventional energy generation in 2016 was around two-thirds the net capacity of clean energy sources, or 165 GW. This was largely due to the flourishing of solar panels in China and throughout the world, and solar panel energy generation grew by 50\% to around 74 GW [119]. Various renewable energy sources such as wind, solar, small hydropower, biomass, and wave energy are used. The growth of renewable energy resources over the past decade in India is shown in Figure $4[120,121]$.

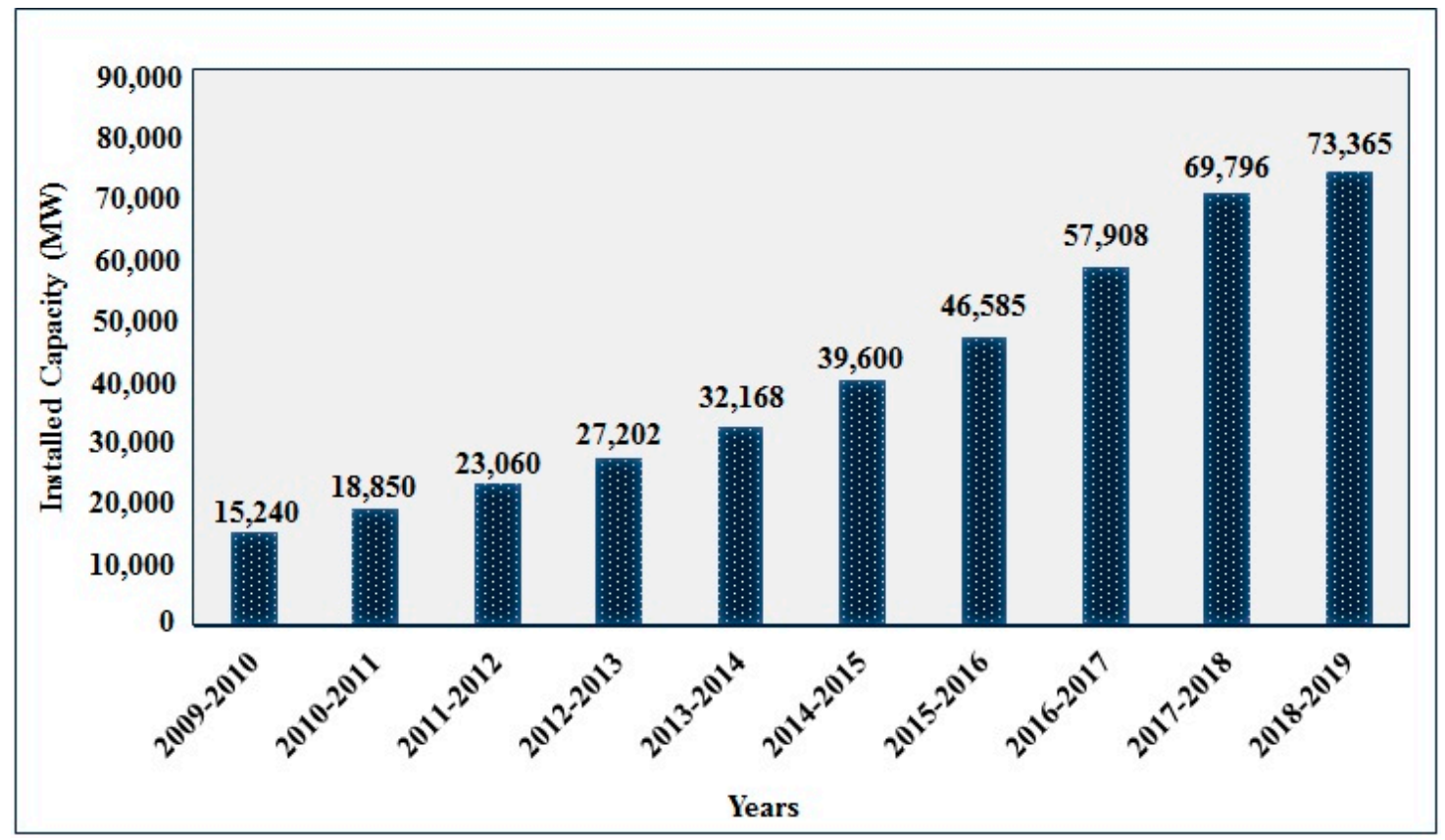

Figure 4. Growth of renewable energy resources in India over the last 10 years $[120,121]$.

In India, non-conventional energy capacity is believed to double by 2022. India generates 21,651 MW of solar power and 34,046 MW of wind power, which is much higher than countries such as Bangladesh, Thailand, France, and Sri Lanka [122].

Progressively, India has sufficient land to install solar energy plants. In 2018, the government decided to support manufacturers with a strategy to reduce tariffs on projects by increasing the protection for PV panels by forcing developers to buy panels at a higher cost [123]. There is also efficient wind velocity availability throughout the year for the generation and reasonable implementation of biomass production. Further, several rivers are available for generation by means of small hydropower plants. The installed capacity of various renewable energy sources is shown in Figure 5 [121,122]. There is also good availability of waves to develop wave energy in the future. 


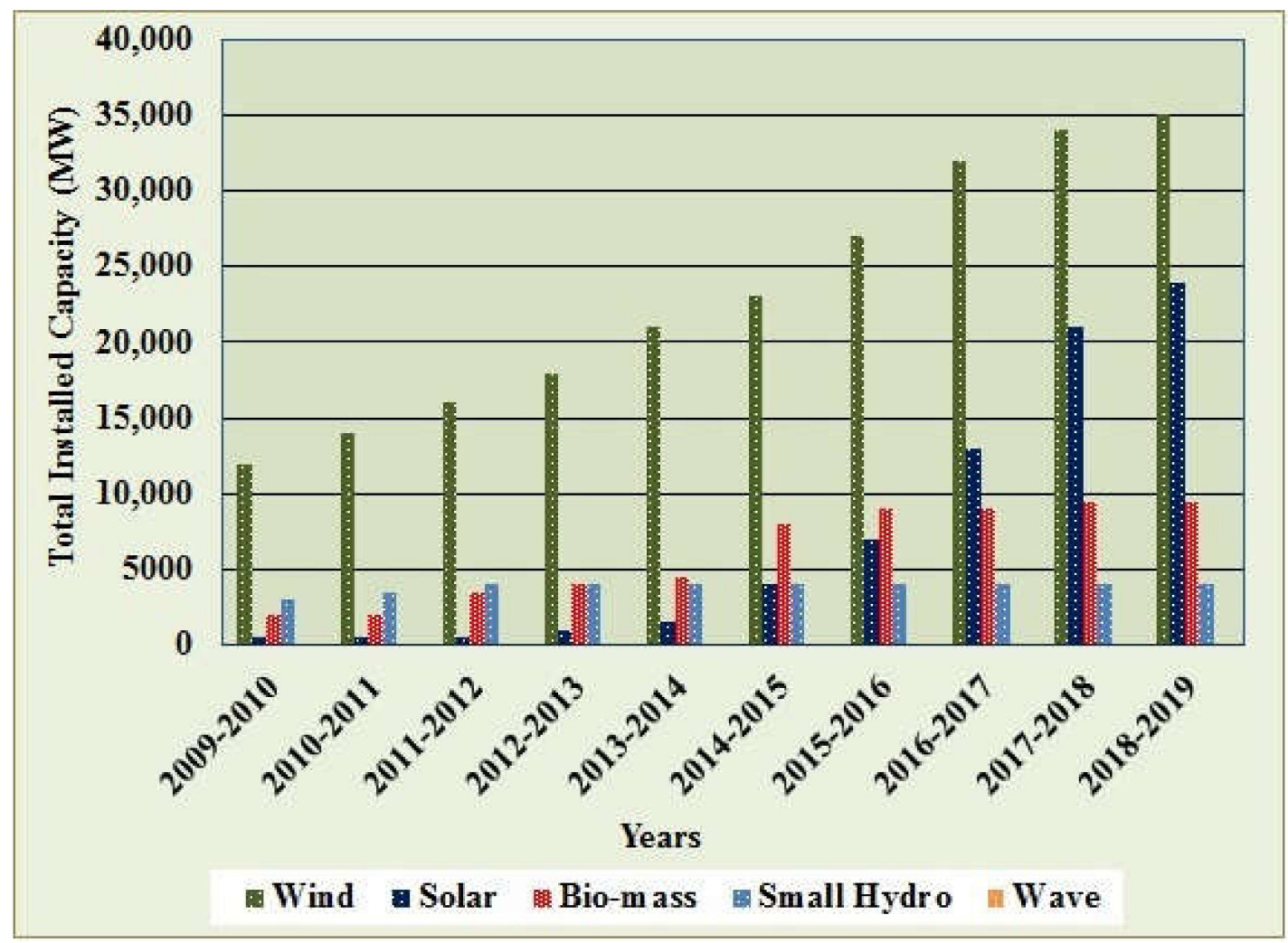

Figure 5. Installed capacity of various renewable energy sources in India as of March 2019.

\section{Technological Development in India}

One of the most significant developments in the solar field is the newly developed Godawari Green Energy Limited (GGEL), which has initiated the first solar thermal plant at a site in Rajasthan. The plant was initially designed to generate $50 \mathrm{MW}$. This project is intended to supply to 2.5 million homes in the area. At full capacity, the plant is designed to generate 118,000 MW hours of electricity per year. The technology adopted here is parabolic CSP technology. Unlike thermal coal plants, steam is generated through thermic fluid, which transfers its heat to the water for steam generation [124]. The steam is then used to run the turbines. It is the first-ever CSP plant to be built in the country. Unlike other thermal plants, this plant does not add harmful air pollutants and greenhouse gases to the atmosphere. About 82,228 t of $\mathrm{CO}_{2}$ was saved last year [125].

The MNRE introduced the Center for Wind Energy Technology (CWET) to develop wind energy in India. The CWET focuses not only on repowering the old mills but also replacing them with higher capacity turbines if needed. The World Institute of Sustainable Energy (WISE) has a similar approach to CWET for the wind assessment program. The CWET finds sites that are suitable for wind power and has found areas that have wind potential of more than $200 \mathrm{~W} / \mathrm{m}$ at a $50 \mathrm{~m}$ height [126]. To obtain better efficiency in a wind energy conversion system, the structure of the machine is improved to avoid the problems pertaining to voltage sag and swell [127]. A PMSG is highly preferred for stable operation and better efficiency [128]. To attain maximum power from a PMSG, an MPPT controller should be employed to effectively track the speed reference of the generator [129].

Apart from the technological developments in India, the country also shows its fullest efforts in implementing more projects on non-conventional energy resources. The significance of the developments in the country is shown with a detailed case study on the non-conventional energy potential of Maharashtra state. The current supportive circumstances for equipping non-conventional energy are reviewed in further sections. 


\section{Renewable Energy Scenario of Maharashtra: A Case Study}

Maharashtra is the third largest state geographically and the second most populous state in India. It has the most business enterprises and employment opportunities compared to other states. Maharashtra is located in the western part of India; its global location is shown in Figure 6. Renewable energy has a $15 \%$ share of the total electricity generation capacity of the state. The current mix of conventional and renewable energy sources of the state is presented in Figure 7. The share of the installed capacity of renewable energy sources is far from conventional sources at about $9.2 \mathrm{GW}$, which is only about $22 \%$. It consists of wind as a major stake at $4.7 \mathrm{GW}$, followed by biomass at about $2.5 \mathrm{GW}$, as given in Figure 7. The segments of solar and mini-hydro are not large in the energy mix.

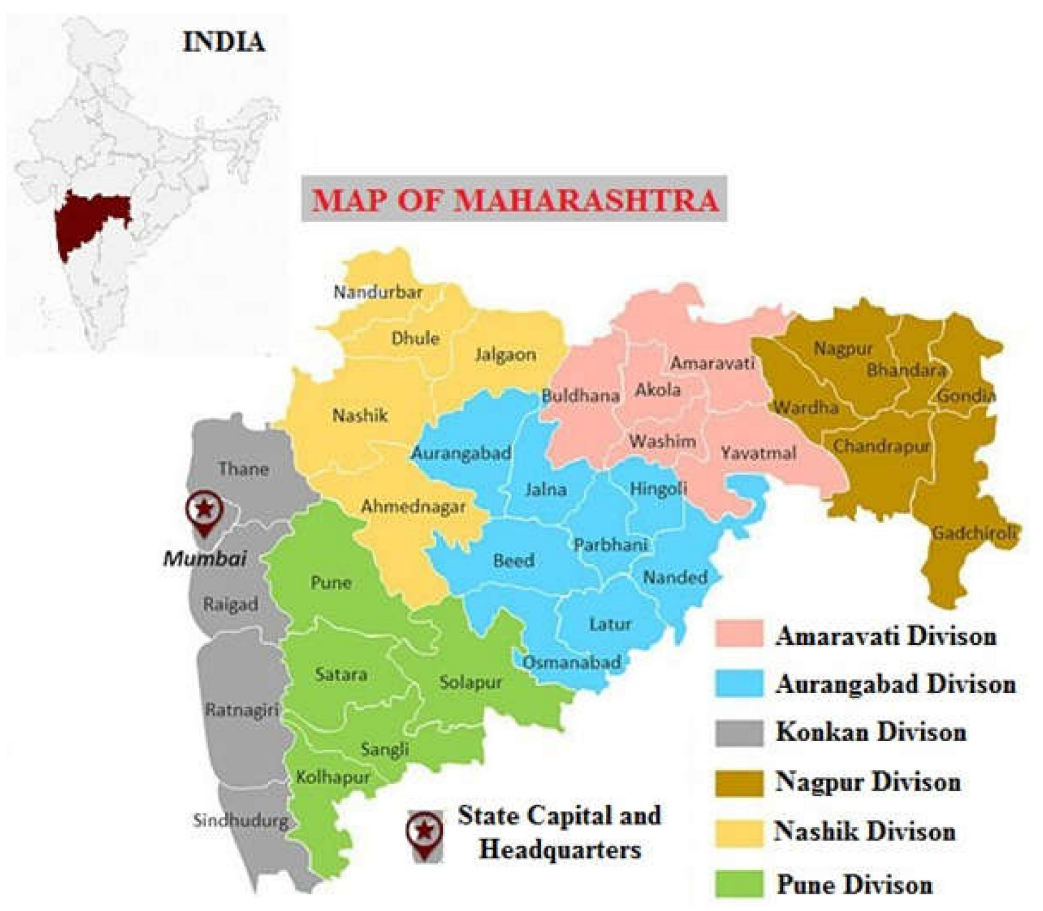

Figure 6. Location of Maharashtra on a global map.

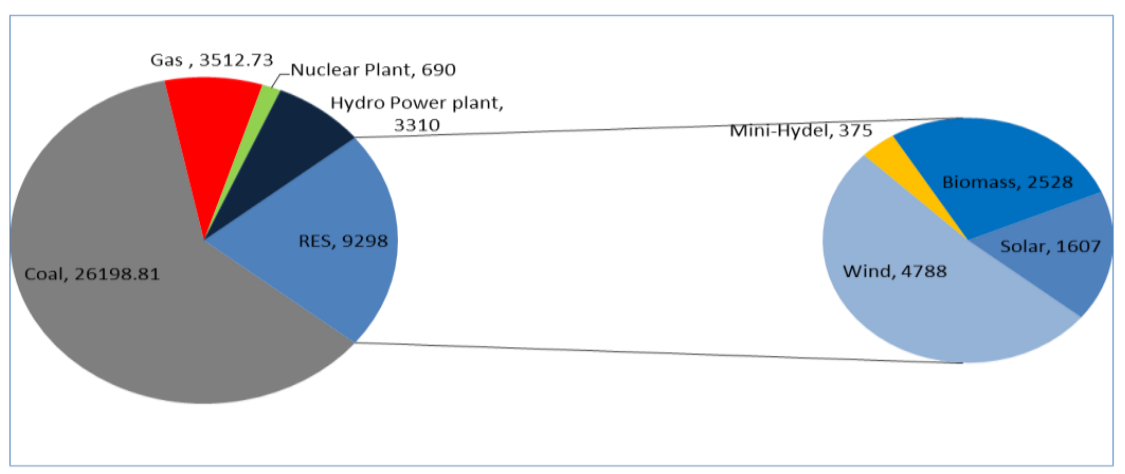

Figure 7. Energy mix of the state in MW (as of March 2020).

The state has the Maharashtra State Electricity Board (MSEB), which is an electricity regulation committee. The MSEB was restructured into four companies on 6 June 2005 [130]:

- The Maharashtra Electricity Regulatory Commission (MERC) was organized to improve the efficiency and economy of the power sector and to manage the amount of power production, communication, and transportation in order to acknowledge the significance of users and other partners [131]. 
- Maharashtra State Power Generation Company Limited (MSPGCL) was organized by the Indian Companies Act 1956 following the agreement of the government of Maharashtra to restructure the MSEB [132].

- Maharashtra State Power Transmission Company Limited (MSPTCL) is a fully possessed corporation under the government of Maharashtra that was coordinated by the Companies Act after reorganizing the former MSEB [133].

- Maharashtra State Power Distribution Company Limited (MSPDCL) transmits power to consumers across the state, except in some areas of Mumbai [134].

The various projects undertaken by the Maharashtra government and the private sector to develop renewable energy systems in the state are as follows:

\subsection{Solar Energy}

Maharashtra is one of the three best regions in India for solar installation and has a massive potential for solar power production. There are about 250-300 clear sunny days, with the possible irradiation of 4 to $6 \mathrm{kWh} / \mathrm{m}^{2}$ in a day. Hence, it has the potential to produce about 1.5 million units/MW/year through the solar photovoltaic system and up to 2.5 million units/MW/year through the solar thermal system. Maharashtra State Power Generation Company (MAHAGENCO) authorized $515.01 \mathrm{MW}$ as of October 2017, which is about 3.3\% of the overall equipped quantity of solar power plants in India [135]. It has six solar cities: Nagpur, Kalyan-Dombiwali, Shiridi, Thane, Aurangabad, Nanded, and Pune. Out of these cities, Nagpur is declared as a model solar city and Shiridi and Thane are declared as pilot solar cities [136]. There are three major solar parks in Maharashtra with a high capacity for generation: Sai guru, Patoda, and Dondaicha solar parks. The various solar parks along with their approved capacity as of June 2018 are presented in Table 1.

Table 1. List of solar parks approved under scheme of the Ministry of New and Renewable Energy (MNRE) [137].

\begin{tabular}{|c|c|c|c|}
\hline S1. No & Solar Park & Approved Capacity (MW) & Location \\
\hline 1 & Sai Guru (Pragat) & 500 & $\begin{array}{l}\text { Bhamer village, Taluka-Sakri, Dhule } \\
\text { district }\end{array}$ \\
\hline 2 & Patoda (Paramount) & 500 & $\begin{array}{l}\text { Tambrajuri and Wadsari villages, Talka } \\
\text { Patoda, Beed district } \\
\text { Vikran and Meti villages, }\end{array}$ \\
\hline 3 & Dondaicha & 500 & $\begin{array}{l}\text { Talka-Dondicha, Dhule district, } \\
\text { Maharashtra }\end{array}$ \\
\hline 4 & Latur & 60 & $\begin{array}{l}\text { Sindala Lohara, Taluka-Ausa, Latur } \\
\text { district } \\
\text { Babhulgaon (20 MW), Pardi Takmor ( } 30\end{array}$ \\
\hline 5 & Washim & 170 & $\begin{array}{l}\text { MW), Saykheda (20 MW), Dudhkheda } \\
(60 \mathrm{MW}) \text {, and Kanzara ( } 40 \mathrm{MW})\end{array}$ \\
\hline 6 & Yavatmal & 75 & $\begin{array}{l}\text { Mangladevi ( } 25 \mathrm{MW}) \text {, Pimpri Ijara ( } 25 \\
\text { MW), and Malkhed ( } 25 \mathrm{MW})\end{array}$ \\
\hline
\end{tabular}

In addition to the above, Maharashtra state also promotes special projects that are eco-friendly and beneficial, such as the following:

\subsubsection{Solar Power Traffic Signals}

The Maharashtra government uses solar power very efficiently with different methods. One method is solar-powered traffic signals. The initial cost of this project is very high, but it is highly profitable as it can be sustained for many years with minimum maintenance cost. By using this method, traffic signals can be made to work effectively. The first installation was done by Symtronics and Svam Electronics at Aurangabad by the MEDA [138]. 


\subsubsection{Solar Heat Generation}

Another advanced application using solar energy is solar heaters, which consist of collectors that are flat in shape and are used to raise the temperature of water up to $80^{\circ} \mathrm{C}$. Around $1800 \mathrm{Kcal}$ per square meter of heat is produced using the collectors. The cost will be about Rs $5000 / \mathrm{m}^{2}$, and the collector area will be around $30-70 \mathrm{~m}^{2}$. MEDA determined that the steam produced from industries by burning coal or wood is not efficient and resolved that solar heaters that are more efficient could be developed [139].

\subsection{Wind Energy}

India has enormous resources for the production of wind energy as it is a peninsula, with three sides covered by water and one side by land. As Maharashtra is in the central-western region of India, one side is surrounded by the Arabian Sea, whose coastal length is about $720 \mathrm{~km}$. The total installed capacity of wind energy in Maharashtra is about 5439 MW, whereas India's total capacity is about 51,130 MW as of March 2020 [140]. About 50 producers are enrolled with the state nodal organization MEDA for the production of wind projects. Areas with an annual average wind density as high as $200 \mathrm{~W} / \mathrm{m}^{2}$ were examined for wind power projects. About 339 stations were selected for this category in India, with 40 sites in Maharashtra [141,142]. Most of the wind power plants in the state are highly ranked in terms of installed capacity. Table 2 represents the major wind power plants in Maharashtra.

Table 2. Major wind power plants in Maharashtra.

\begin{tabular}{ccccc}
\hline SI. No & Power Plant & Producer & Location & Capacity (MW) \\
\hline 1 & Brahmanvel wind farm & Parkh Industry & Dhule & 526 \\
2 & Dhalgaon wind farm & Gade Export & Sangli & 275 \\
3 & Vankuswade wind park & Suzlon Ltd. & Satra district & 254 \\
4 & Vaspet & ReNew Power & Vaspet & 144 \\
5 & Jath & ReNew Power & Jath & 84 \\
6 & Welturi & ReNew Power & Welturi & 75 \\
\hline
\end{tabular}

In Table 2, it is noted that the Brahmanvel wind farm, in Dhule district, has the highest share, with a capacity of about $526 \mathrm{MW}$ [143]. Dhalgaon wind farm is the second-largest wind power plant.

\subsection{Small Hydro}

India is one of the largest countries in the world, with many rivers. The five major rivers are Ganga, Godavari, Krishna, Tapti, and Narmada, four of which flow in Maharashtra state. The Narmada, which flows through the state, is not a major river in the state [144,145]. With these strong resources, a total of 193 MW of installed capacity is presently commissioned in the different regions, as shown in Figure 8. 


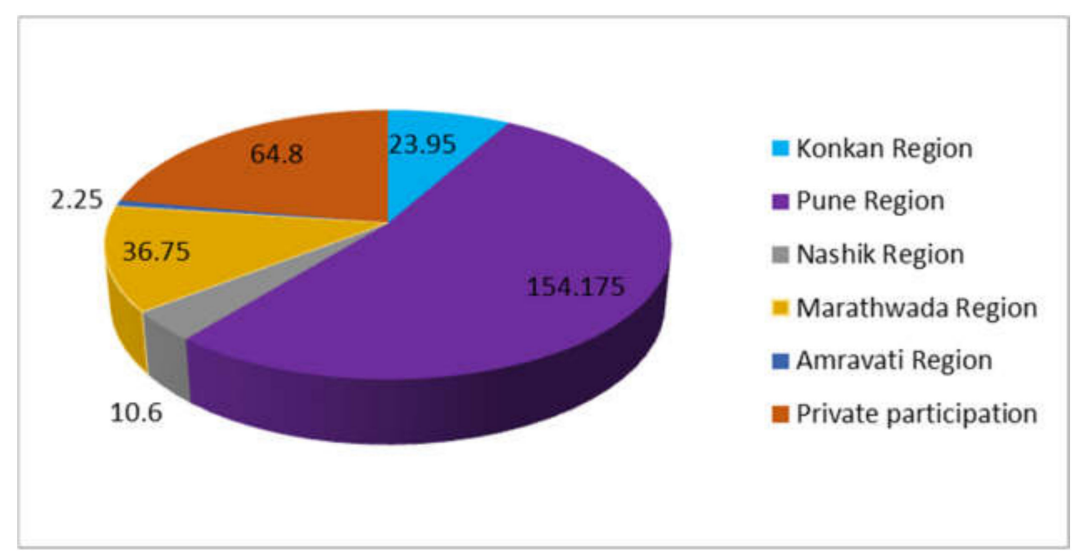

Figure 8. Installed capacity of small hydropower generation (MW).

\subsection{Biogas}

The tariffs for co-generation power projects vary from time to time by MERC. Due to the attractive cost, there are about 102 projects with a capacity of about 1775.85 MW [146]. On 19 April 2016, the commission declared that the cost for a co-generation project is about 6.734 per unit. According to a study by MNRE and the government of India, the potential of the country is about $3500 \mathrm{MW}$, and the potential of Maharashtra is about $1251 \mathrm{MW}$. There are about 202 registered sugar factories in Maharashtra. MEDA's schemes in sugar mills are one of the main reasons for the registration of many sugar mills. To create greater impetus in the renewable energy sector, the Urajankur Nidhi Trust [147], which was established in 2006 by the government of Maharashtra, contributed the amount of Rs 418 crores.

The industrial waste obtained in Maharashtra has the capability of producing energy. The total potential of power production from waste will be around $350 \mathrm{MW}$ according to the data collected by the Tata Energy Research Institute. Power generated from waste is also considered as a source by the government of Maharashtra. Under the comprehensive policy of the MEDA 2012 Prospective Plan, $200 \mathrm{MW}$ is fixed as the target of power generation from organic and inorganic degradable waste [148]. A clear overview of the generation of renewable energy from 2010-2020 is shown in Table 3. The state is also taking initiatives to develop the use of renewable energy sources through policies, which are discussed in the table. In order to promote renewable energy resources, the state government of Maharashtra has authorized various new projects, which are presented in the next section. 
Table 3. Extensive progress and policies of renewable energy in Maharashtra.

\begin{tabular}{|c|c|c|c|c|}
\hline Resources & Progress from 2010 to 2020 & & Installed Capacity Status & Illustration \\
\hline Wind energy & $\begin{array}{l}\text { - Maharashtra stands in third position as of February } 2020 \text {, with an } \\
\text { installed capacity of } 5439.38 \mathrm{MW}[149] \text {. } \\
\text { - In the last } 10 \text { years, there was a remarkable growth in wind turbines, } \\
\text { with an installed capacity of } 4400 \mathrm{MW} \text {. } \\
\text { - Leading manufacturers of wind turbines, such as ReNew, Suzlon, and } \\
\text { Vestas, have a presence in the state [149]. } \\
\text { - The private sector has invested more than Rs } 11,895 \text { crores in wind } \\
\text { generation, involved with the government through } \\
\text { investor-friendly policies. } \\
\text { By 2022, Maharashtra plans to extend its installed capacity to } 7600 \mathrm{MW} \text {. } \\
\text { - Under renewable purchase obligation (RPO), wind energy projects are } \\
\text { favored for installation by approval through a no objection certificate } \\
\text { (NOC) issued by the pollution board in 2008. }\end{array}$ & 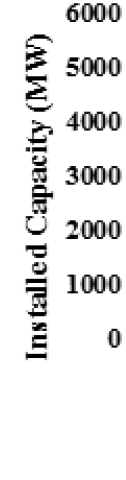 & 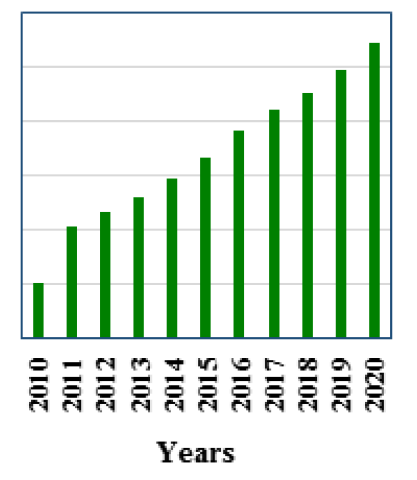 & $\begin{array}{c}100 \text { MW Chand-Bibi Mahal Wind turbine } \\
\text { plant, Ahmednagar }\end{array}$ \\
\hline Solar energy & $\begin{array}{l}\text { - A solar rooftop system for } 50 \mathrm{MW} \text { was sanctioned by MEDA } \\
\text { (Maharashtra Energy Development Agency) in } 2018 \text { [150]. } \\
\text { - Solar lanterns covered } 360^{\circ} \text { with PV modules and solar home lights were } \\
\text { provided by the government to rural areas. } \\
\text { - The Maharashtra government approved the solar energy policy in } \\
\text { January 2016, encouraging purchases by individuals and the public and } \\
\text { private sectors. } \\
\text { Banks are ready to give loans of } 15 \text { crore under priority sector lending for } \\
\text { large-scale industries [151]. } \\
\text { - Third-party sales were permitted by MEDA in } 2015 \text { with registered } \\
\text { documents [151]. } \\
\text { - The amount of Rs } 2682 \text { crores was claimed by the state government for } \\
\text { installing rooftop solar power plants on government buildings with a } \\
\text { 100\% subsidy, and a } 15 \% \text { subsidy for people below the poverty line [151]. } \\
\text { - The state set a target of achieving } 12 \mathrm{GW} \text { solar power by } 2022 \text {. }\end{array}$ & 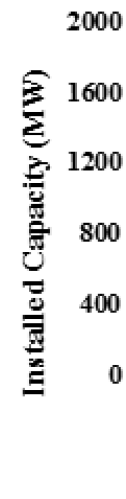 & 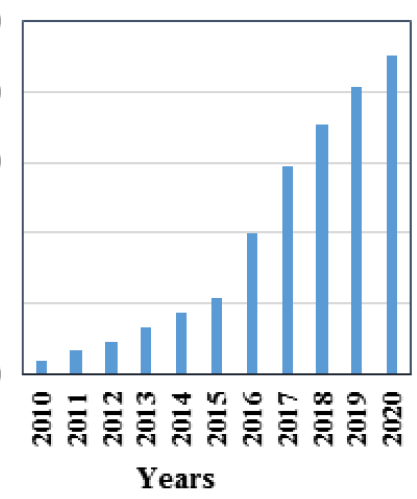 & 3 MW Tata solar power plant, Mulshi, Male \\
\hline
\end{tabular}


Table 3. Cont

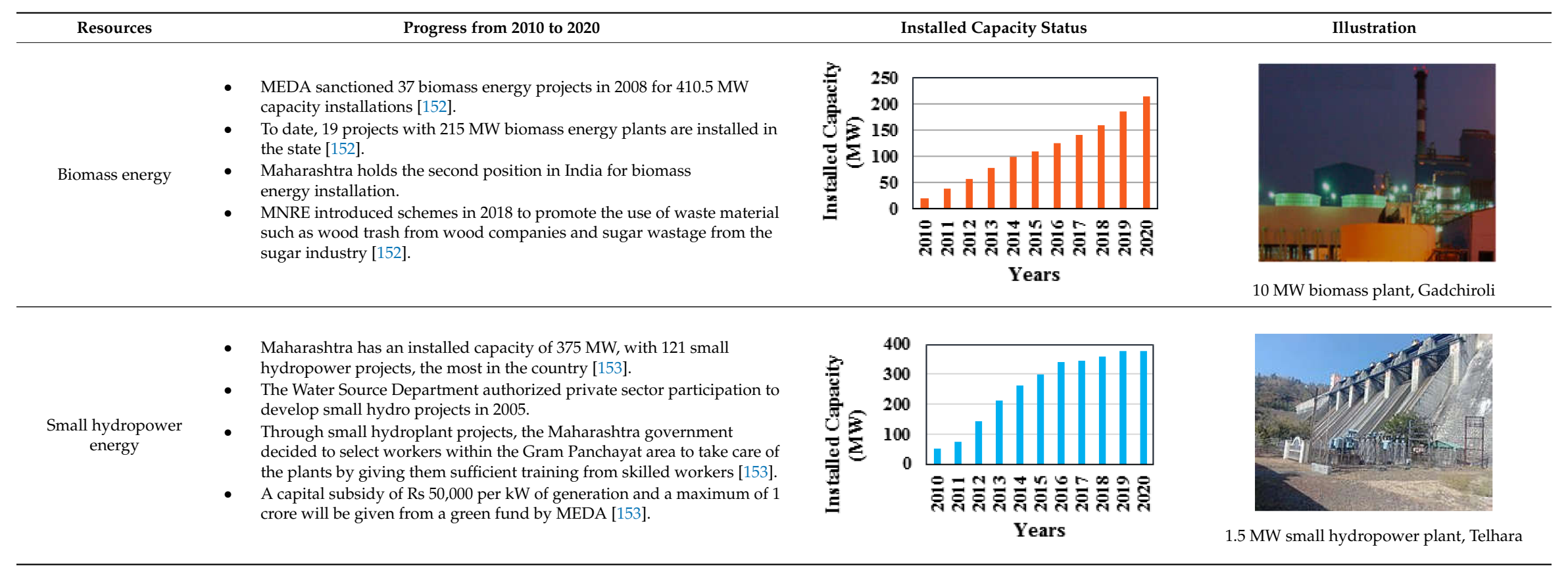




\section{Other Potential Alternative Energy Resources}

The state government of Maharashtra is seeking new ways to develop renewable energy systems in the form of geothermal, wave, and tidal energy. The upcoming alternative renewable energy projects are as follows.

\subsection{Geothermal Energy}

Geothermal energy is a non-conventional energy resource that the Indian government is showing more interest in; as a result, the state of Maharashtra has also shown interest. Geothermal plants apply to certain areas in the country, including Maharashtra. Three provinces in the state are suitable for geothermal projects: the West Coast (Konkan), Narmada-Tapi Garben, and Godavari Valley provinces [154]. The carbon emissions from existing geothermal energy worldwide are about $122 \mathrm{~kg}$ of carbon dioxide MWh, which is about one-eighth that of conventional coal-fired plants. Thus, this can be used as an alternative to coal.

\subsection{Wave Energy}

As India is surrounded by the Arabian Sea in the west and the Indian Ocean in the south, there is a huge possibility of producing a wave energy of about 40,000 MW. It is also possible to produce wave energy in Maharashtra, which has been proved in studies. The studies discovered that some areas such as Vengurla Rocks, Malvan Rocks, Redi, Pawas, Ratnagiri, and Girye can produce wave energy. The overall capacity of wave energy on this coast of the state is about 500 MW [155]. A survey conducted by the Center for Earth Science Studies, Thiruvananthapuram, examined the potential wave energy on the coast of Maharashtra and found 11 sites that could each produce an average of about 6-7 MW per site. For this reason, the government of Maharashtra announced some attractive policies to encourage the private sector to invest in this field. The wave energy capacity of possible stations in Maharashtra is presented in Table 4.

Table 4. Feasible sites of wave energy in Maharashtra.

\begin{tabular}{cccccc}
\hline \multicolumn{5}{c}{ Wave Energy on Maharashtra Coast } \\
\hline \multicolumn{2}{c}{ Offshore Avg. Wave Energy $\mathbf{~ k W / m ~}$} & \multicolumn{2}{c}{ Coastal Avg. Wave Energy kW/m } \\
\hline Site & Annual & (June-August) & Site & Annual & (June-August) \\
Vengurla Rocks & 8.001 & 20.612 & Girye & 5.902 & 14.212 \\
Square Rocks & 6.7901 & 16.643 & Vijaydurg & 5.864 & 13.583 \\
Redi & 6.351 & 16.572 & Ambolgarh & 5.743 & 13.481 \\
Malvan Rocks & 6.910 & 16.731 & Kunkeshwar & 5.642 & 13.352 \\
Kura Inset & 5.793 & 13.745 & Pawa Point & 5.361 & 13.102 \\
& & & Wagapur & 5.701 & 13.101 \\
\hline
\end{tabular}

\subsection{Tidal Energy}

The country has the capability of producing power from tidal energy, as it is surrounded on three sides by the ocean. Maharashtra is surrounded by the Arabian Sea on one side, so there is the possibility to produce power from tidal energy [156]. The ministry of renewable energy sources and the government of India together carried out a study to analyze the tidal energy in Maharashtra. There are only two functioning tidal energy power plants in the world: a $240 \mathrm{MW}$ plant in La Rance, France, and a 16 MW plant in Annapolis Royal, Canada. Considering this and based on the current scenario of Maharashtra state, the future energy mix is described in the next section.

\section{Prospective Future Energy Mix of Maharashtra State}

Maharashtra is a leading state in the country in industrialization and urbanization. In order to sustain the fast growth of the population, establishing consistent and affordable energy is imperative. 
The GDP growth in the state is directly proportional to the consumption rate of electricity. Though the progress of energy development of the state is superior to that of other states in the country, the fast-growing demand warrants balanced socioeconomic development. In order to attain this, there needs to be the amplified utilization of RESs, because the state has the biggest base of electricity customers compared to other states. It had a total demand of 24,326 MW as of March 2020, and a mix of energy, predominantly from thermal plants, as shown in Figure 9.

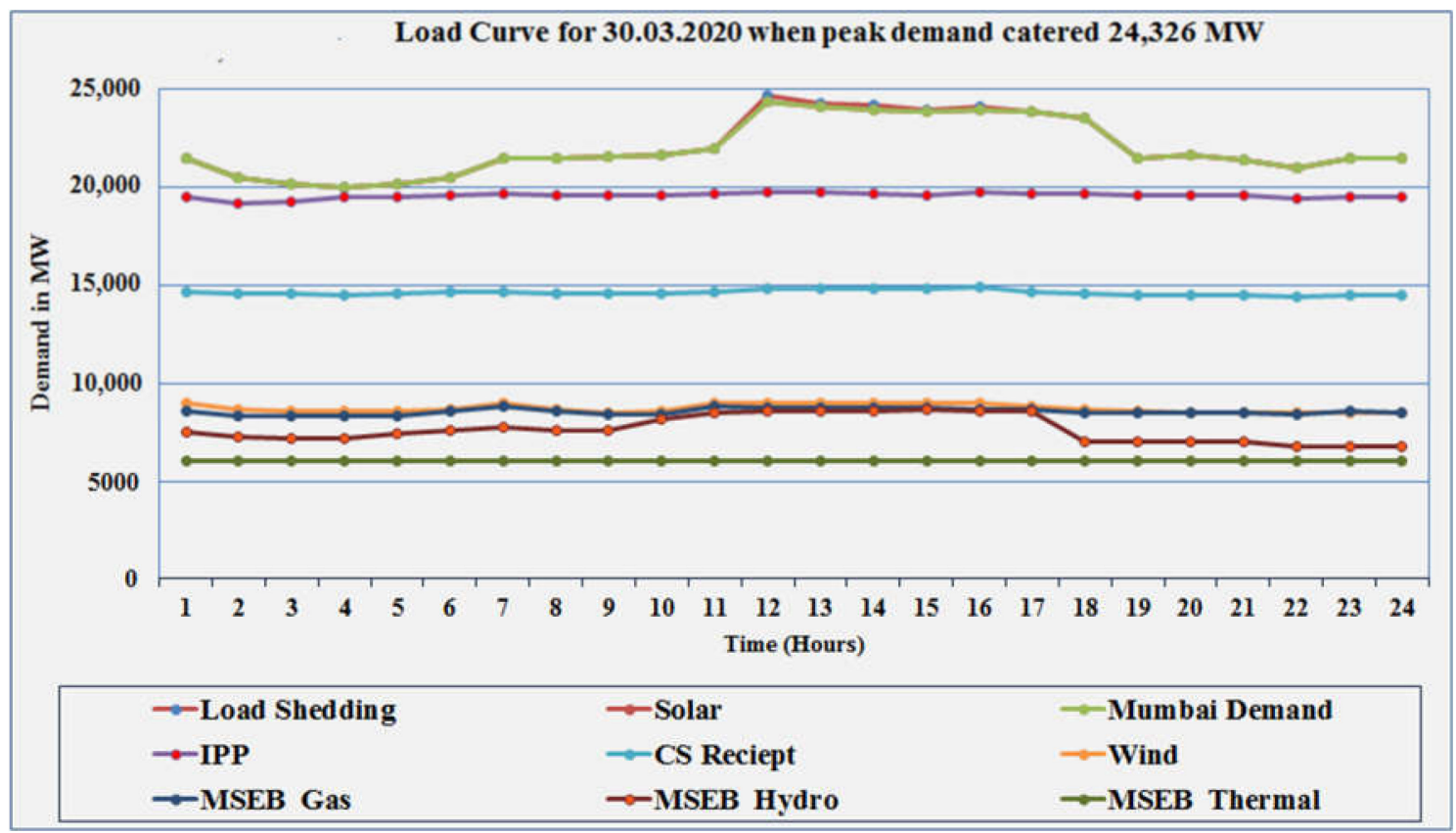

Figure 9. Maharashtra peak energy demand. MSEB, Maharashtra State Electricity Board; IPP, Independent Power Producer; CS, Consumption and Security Receipt.

Though this state has an overall RE potential of about $114 \mathrm{GW}$ specifically for small- and large-scale solar farms, the installed capacity of RES shows a huge gap. As mentioned earlier, Maharashtra has great potential for solar and wind energy resources, but the current trend needs to be improved on a large scale in order for the state to take part in the energy mix at a higher level. The hourly solar and wind energy generation (MWh) during the financial year 2019-2020 are illustrated in Figures 10 and 11.

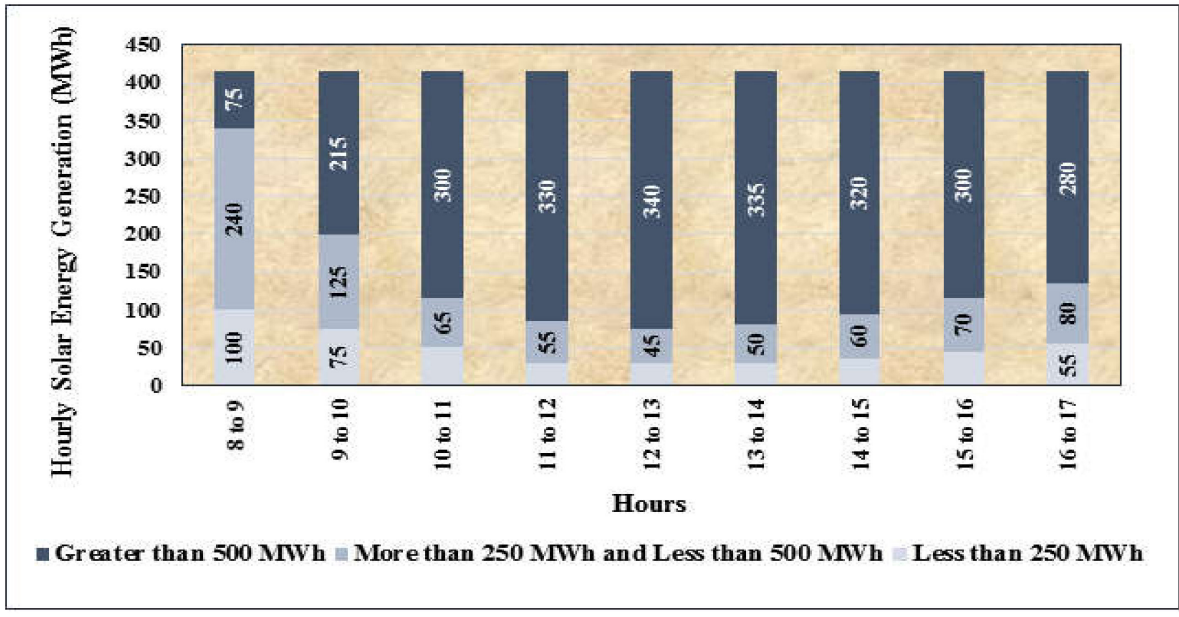

Figure 10. Hourly solar energy generation (as of March 2020). 


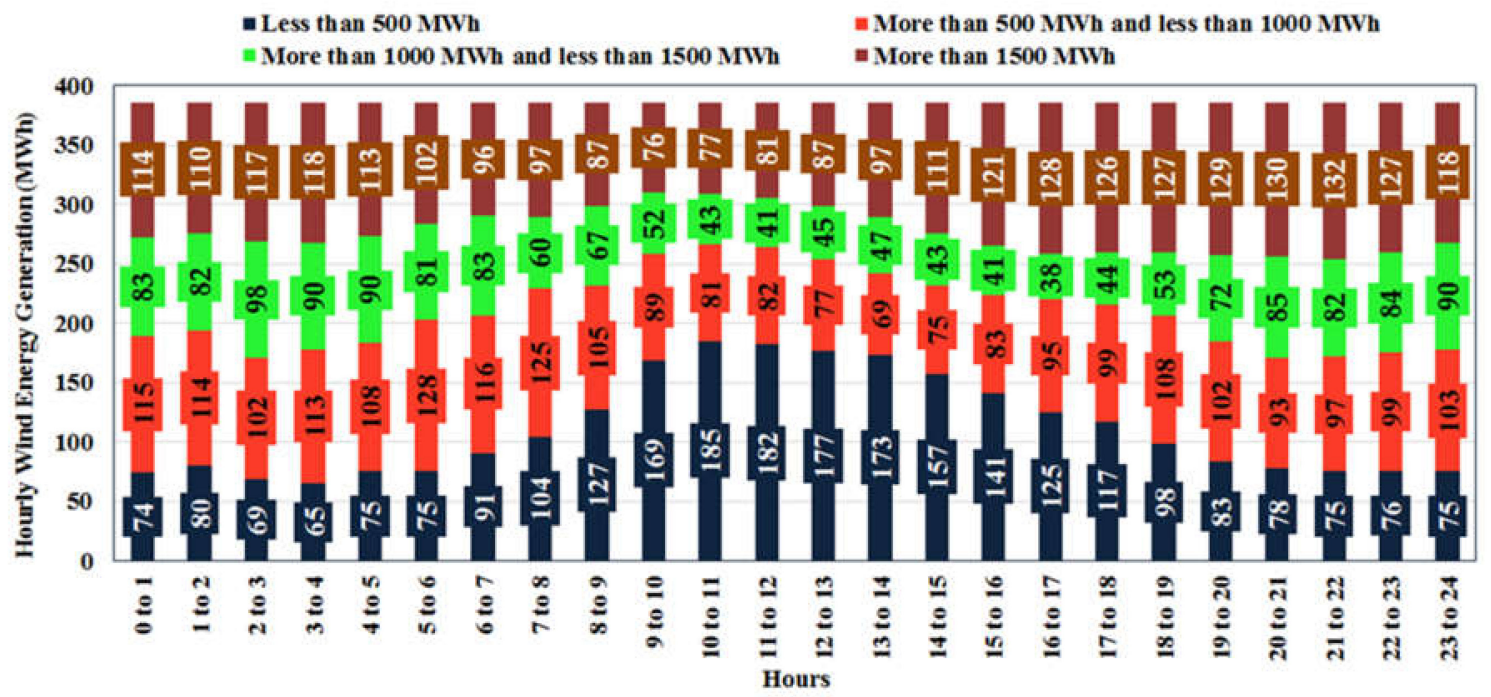

Figure 11. Hourly wind energy generation (as of March 2020).

It can be seen that the extraction of hourly solar and wind power shows great magnitude throughout the targeted period. With this reference, the state working group aimed to attain more RES capacity by 2022. Additionally, the demand rate of the state in 2022 will increase to some extent. Therefore, it is imperative to drive all the potential forms of RES to meet future demand by mixing higher concentrations in overall demand patterns. The targeted RES capacity by 2022 according to MEDA is presented in Figure 12. The current installed capacity of solar generation is about $1.6 \mathrm{GW}$, which lags by about four times the targeted capacity by 2020 . The wind generation capacity of the state lags by approximately $1 \mathrm{GW}$ for target year 2020 and $2.3 \mathrm{GW}$ for the target year 2022. Notably, the biomass generation attained the target for 2022 during the current financial year. Mini-hydro is close to the target and has a higher possibility to obtain the target for 2022. Moreover, as in other businesses, RESs are exposed to different risks from the Covid-19 pandemic. It has been markedly changed by the market segment and technology. Therefore, Maharashtra state should implement a wide-ranging RES policy to promote large-scale solar generation, including grid-connected rooftop and off-grid projects at all potential sites.

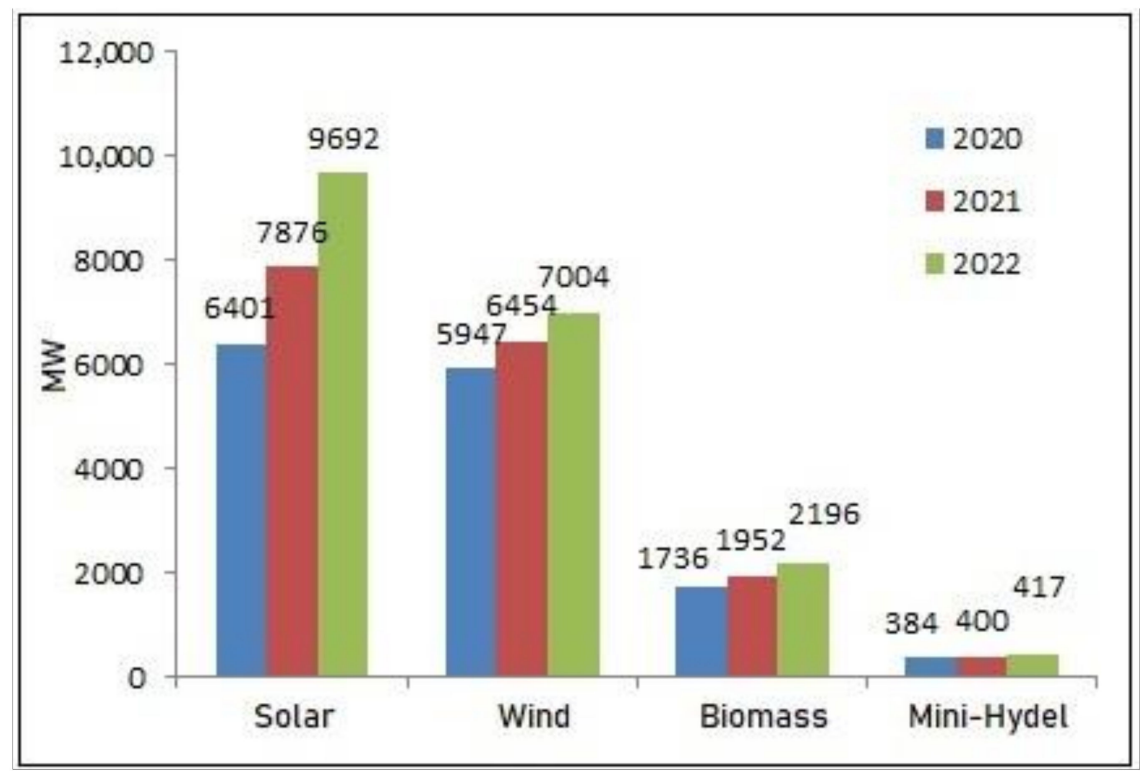

Figure 12. State renewable energy source (RES) target by 2022. 
Upon comparing the above, it is observed that the current installed capacity of solar generation is far from the target. Hence, the state government has planned alternative methods/policies for solar energy, as described below.

\subsection{Solar Power for Farming}

The Maharashtra government set a foundation stone for a pilot project in which the farmlands in the state could get an uninterrupted power supply. The test project will come up at Ralegan-Siddhi, under the government's Mukhyamantri agricultural solar feeder scheme. The central government has allocated Rs 3 crore per plant, enabling the state to generate solar power at cheaper rates, with a plan to save energy over the upcoming years [157].

\subsection{Floating Solar Power Projects}

Floating solar projects, another future application of solar power, are created by making solar panels float on water bodies [158]. The advantages of this project are that land, which is a major constraint for solar installations, is not required, and the evaporation of water can be prevented. The state government plans to install about $250 \mathrm{MW}$ of floating solar panels. The government invited private companies to develop a floating solar project in the Ujani dam, which is located in Solapur district [159]. The topography is the main reason for the selection of this dam, which has flat land with a shallow depth. It is easily accessible from all directions.

Since the state is on track to attain its RES target by 2022, there is a strong need to analyze its potential in various aspects. The below section describes the strengths, barriers, and challenges in obtaining the defined target by MEDA.

\section{Exploration of Possible Approaches and Barriers}

This analysis is based on the internal and external evaluation criteria of the targeted locations. It has been broadly utilized by researchers for energy planning and its challenges. In this regard, the results of this analysis of the sustainable development of the renewable energy sector show the need to work on the strengths, adjust the weaknesses, exploit the opportunities, and prevent threats. So far, the various renewable assets accessible in Maharashtra state have been discussed. In order to gain deeper insight, further study is needed for the following reasons:

- Strategic planning can be done with information provided by the authorities;

- It helps in identifying the core competencies of the nation in the renewable sector;

- Opportunities can be maximized according to the response;

- The nation's strength can be built through its renewable energy process.

In this section, the strengths and opportunities are discussed based on the implemented renewable energy resource policies and developments in the renewable energy sector in Maharashtra. A few barriers and challenges that need to be overcome are discussed.

\subsection{Strengths and Opportunities}

The strengths and opportunities of the state depend on the initiatives taken by the country and the state to develop the use of renewable energy sources.

\subsubsection{Central Government Initiatives}

Windmills are very expensive for the government to install. The Indian government has made various attempts to increase the use of wind energy by publicizing it with attractive policies. Foreign direct investment (FDI) provided 100\% investment for wind energy to reach the installation of $5.5 \mathrm{GW}$ from 2017 to 2019 [160]. Bank loans of up to $\$ 2.3$ million for public utilities with renewable energy and power systems have been allotted by MNRE for every state in India [161]. 


\subsubsection{Geography}

The state has more wind flow throughout the year and is highly suitable for wind turbines. The price and availability of land for wind energy installation are attractive for the public and private sectors. Due to the vast availability of land in the outskirts of the state, wind turbines are installed away from buildings and residential areas to avoid disturbance [162].

\subsubsection{Solar Mission}

With the reduced cost of solar panels, the state set a target to reach 20,000 MW of grid-connected solar power by 2022 through the Jawaharlal Nehru National Solar Mission by reducing the cost of solar power generation. The country wants to achieve a grid tariff parity by 2022 .

\subsubsection{Job Opportunities}

Renewable energy installation brings job opportunities throughout the whole country. Due to an increased demand for renewable energy systems in daily life, job opportunities also keep increasing. For solar, rooftop solar systems have become more popular. Many companies are specially manufacturing rooftop solar systems in Maharashtra, which leads to the requirement for many engineers to test the systems and install them in residential areas.

\subsubsection{Policy Implications}

MNRE, by collaborating with the National Institute of Wind Energy (NIWE), has encouraged the implementation of offshore wind energy projects with policies. The government is keen on the growth of the wind energy sector in India [163]. Maharashtra ranks second after Tamil Nadu in wind power system installation, and it is estimated that the installation capacity could reach $7600 \mathrm{MW}$ by December 2020.

The authorities of Maharashtra have launched many policies to develop non-conventional energy resources. To promote more clean energy resources in the state, the government has announced many policies to promote solar, wind, small hydro, and biomass technologies. Maharashtra has a lot of water resources; many hydro projects and floating solar power projects can be implemented. Additionally, it is in the tropical zone, where more solar projects can be initiated, and the government has issued many policies to promote it. The various policies introduced by the government are presented in Table 5.

Table 5. Policies to promote renewable energy resources.

\begin{tabular}{|c|c|c|}
\hline Year & Incentives & Key Features \\
\hline 2009 & $\begin{array}{l}\text { Endorse solar thermal systems for } \\
\text { air-heating/steam-generating } \\
\text { applications, solar buildings, and } \\
\text { Akshay Urja shops [164]. }\end{array}$ & $\begin{array}{l}\text { Promotes the extensive use of solar thermal systems } \\
\text { for air-heating and steam-producing applications and } \\
\text { the use of passive solar techniques in the } \\
\text { building layout. } \\
\text { Reduces the use of non-renewable energy by storing } \\
\text { electricity and fossil fuels in buildings and industrial } \\
\text { and commercial structures. }\end{array}$ \\
\hline 2012 & $\begin{array}{l}\text { Small wind energy and hybrid } \\
\text { systems program [165]. }\end{array}$ & $\begin{array}{l}\text { - Installing aero-generator systems on telecom towers } \\
\text { that will also be eligible for central financial } \\
\text { assistance (CFA) under community users. } \\
\text { A new type of tested small wind turbine model with } \\
\text { a maximum } 500 \mathrm{~kW} \text { capacity. }\end{array}$ \\
\hline 2013 & Wind power policy [166]. & $\begin{array}{l}\text { - Non-agricultural lands are being used for wind } \\
\text { power plants. } \\
1500 \mathrm{MW} \text { capacity would be developed to meet the } \\
\text { procurement necessity of transmission license under } \\
\text { the RPO (Renewable Purchase Obligation) regime. }\end{array}$ \\
\hline
\end{tabular}


Table 5. Cont.

\begin{tabular}{|c|c|c|}
\hline Year & Incentives & Key Features \\
\hline 2014 & $\begin{array}{l}\text { Bagasse/agricultural waste-based } \\
\text { co-generation power policy [160]. }\end{array}$ & $\begin{array}{l}\text { - Farmers are additionally benefitted by this project. } \\
\text { This project has a target of } 1000 \mathrm{MW} \text { for the } \\
\text { generation of electricity. }\end{array}$ \\
\hline 2014 & Small hydropower policy [125]. & $\begin{array}{l}\text { - Promotes a target of } 400 \mathrm{MW} \text { with projects of up to } 25 \\
\text { MW each. } \\
\text { - A capital subsidy of Rs 50,000 per } \mathrm{kW} \text { of generation } \\
\text { capacity is provided by MEDA. }\end{array}$ \\
\hline 2015 & Waste to energy policy [167]. & $\begin{array}{l}\text { - Compensation toward costs incurred on evacuation } \\
\text { schedule, up to a maximum of Rs } 1 \text { crore/project } \\
\text { after authorization. } \\
\text { Relief of electricity duty for captive utilization of up } \\
\text { to } 10 \text { years from the date of authorization. }\end{array}$ \\
\hline 2015 & Biomass-based power policy [168]. & $\begin{array}{l}\text { - A target } 300 \mathrm{MW} \text { capacity for the biomass power } \\
\text { project is set. } \\
\text { A capital subsidy of Rs } 1 \text { crore per plan will be } \\
\text { provided for biomass-based power projects. }\end{array}$ \\
\hline 2015 & Solar power policy [137]. & $\begin{array}{l}\text { - } \quad 7500 \mathrm{MW} \text {-capacity solar power plants to be installed. } \\
\text { Policy also focuses on promoting solar park and } \\
\text { rooftop projects. }\end{array}$ \\
\hline
\end{tabular}

\subsection{Barriers and Their Significance}

The main barriers mainly have to do with the lack of development and knowledge; the infrastructure facilities; improving the demand-supply gap; developing the infrastructure; and social, economic, and technical barriers.

\subsubsection{Social Barriers}

An important barrier is evaluating the utilization of coal and other fossil fuels in order to overcome the emission of hazardous gas. In Maharashtra, there is more coal usage. The government is implementing many social campaigns to emphasize the importance of renewable energy in rural areas. The vision of MEDA is to develop fully renewable energy sources equipped for rural areas by 2030 .

\subsubsection{Technical Barriers}

The technical barriers have to do with a lack of knowledge in managing and operating renewable energy systems. In many rural areas of Maharashtra, skilled workers are not very involved in the work, as there is much less use of renewable energy resources in rural areas. These barriers may stem from concerns surrounding the impact on the local environment.

\subsubsection{Auxiliary Barriers}

Many studies show that solar panels have decreased efficiency due to dust on the panels. Sometimes the weather conditions and improper panel design will lead to low efficiency $[169,170]$. This will lead to reduced lifetimes of panels and less profit for investors, or it may lead to loss. Another study indicates that the lack of storage technologies and the shortage of certain materials are other obstacles that must be dealt with to improve the status of PV installations in the country $[171,172]$.

\subsubsection{Institutional Barriers}

The absence of planning and participation between the various bureaus, academies, and other shareholders slows the growth in progress for non-conventional energy [173]. Such gaps in the 
application of programs and lagging inter-institutional participation reduce the trust of financers in financing renewable energy.

\subsubsection{Technological Barriers}

For many new non-conventional energy technologies such as solar thermal, the liability of automation is immense. Since automation is at the advancement stage, the liability is not distinctly familiar. Some non-conventional energy technologies are identified by the absence of minimal guidelines in terms of persistence, accuracy, accomplishment, etc., thereby influencing their broad commercialization. One of the considerable constraints facing RES such as solar is the immense cost of establishing a solar plant.

\subsubsection{Subsidy Barriers}

MEDA is still waiving the subsidies for coal to power generation in many parts of Maharashtra. Renewable energy utilization is not yet fully implemented within the state or in the country, where the government is still holding it up in many areas. It shows that renewable energy is one of the viable options in India.

\subsubsection{Political Concerns}

Political concerns will keep services stopped once they start or in the middle of installation. The main issue is that the leading party will have an eye on implementing policies related to renewable energy, and with a change in leadership, after a while the installation process will be halted for some time. This affects the society regarding the power generation plan.

\subsubsection{Economic Crisis}

The effective utilization of renewable energy resources requires proper technologies. Such technological advancement is only possible via market openness and institutional innovation, which will result in locally developed systems to harness renewable energy. It will also allow for the development of local manufacturers, which will greatly reduce the cost of urban renewable energy installations in the country.

\subsubsection{Lack of Awareness}

In many regions of the state, there is no public awareness of the importance of renewable energy systems. Mainly for households, renewable energy has not had much impact, which leads to the use of more reliable coal and other fossil fuels.

The brief study carried out in this section identified the various aspects of the state by considering the strengths, opportunities, and overall barriers related to renewable implementation in Maharashtra state. However, strong suggestions and recommendations are presented in the section below in order to attain target capacity by 2022, which can act as a driving force and provide additional support to the state government.

\section{Recommendations and Suggestions}

Although the state faces numerous concerns about and barriers to the future energy mix, there are some suggestions and recommendations, which are discussed below.

\subsection{Formulation of New State RE Policy}

There is an urgent need to formulate a new widespread renewable energy policy that encourages the united expansion of all viable resources in the state. This policy should be adopted by considering a clear roadmap and targets for the development of renewable energy sources. It should emphasize blockages, particularly providing net metering and grid evacuation. Additionally, there should be a 
clear plan to forecast solar and wind generation for the future. Moreover, the targeted policy should represent all the issues and challenges faced by RES generation, as discussed in the previous section.

\subsection{Using Advanced Optimization Tools}

Wind and solar energy are supremely renewable energy sources. This has been widely established worldwide due to the strong seasonal variations in resource extraction and accurate predictions of wind and solar resources. Several optimization techniques are adopted to estimate wind speed distribution and solar irradiance in an effective manner. For instance, the wind characteristics and wind potential of onshore, offshore, and nearshore locations can be statistically analyzed with wind distribution methods. Further, resource assessments are carried out using artificial intelligence and soft computing techniques with the aid of moth flame optimization [174]. This leads to the superior results of complex problems and parameter estimations for any targeted location.

\subsection{RES-Based Rural Electricity Service}

In India, there are still states that fail to provide access to electricity in rural areas. However, Maharashtra state attained complete electrification status under various state and central schemes. Maintaining stability and continuity are the major concerns due to poor power quality. This will be resolved by creating a network of RES-based micro-grids in rural places that can enhance the quality of power. Additionally, a micro-level entrepreneurship program might be initiated to attract lower-level investors.

\subsection{Better Financial Provision and Incentives}

The state government should focus on developing integrated RE in viable locations by providing the following opportunities:

$>$ Interest waivers on loans offered for RES-based projects;

$>$ Increased margin of incentives;

$>$ Directions for rural people in terms of the finance, commission, and operation of RES projects.

\subsection{Standardization}

In order to maintain the quality of RES integrated systems, suitable technical standards should be developed by state agencies collaborating with BIS (Bureau of Indian Standards). This can improve the power quality of the system, particularly in RES integration applications. However, a special task should be enforced to apply the developed standards to lower-level investors, particularly in rural areas.

\subsection{Support from Private Agency}

State agencies could support private agencies for the large-scale deployment of solar or wind projects by clearing the land acquisition process, particularly in areas with good potential. Sometimes, state agencies could lease state-owned sites to private developers to attract high-level investment in RES projects. Additionally, it could simplify the subsidy process.

\subsection{Recommendations for Researchers}

The Maharashtra government faces a major constraint in terms of available land for the development of new projects. So, future researchers can focus on innovative projects that can be developed on a smaller or alternative footprint. One such project is floating solar power, which is being developed. Researchers can focus on developing more solar power projects, as Maharashtra is located in the tropical zone, and more hydro projects are also encouraged, as it has a lot of reservoirs and is rich in water resources. 


\subsection{Schemes for Agriculture Consumers}

The state should focus on increasing the support given to agricultural consumers employing solar irrigation pumping schemes. The state could provide appropriate infrastructure to farmers to transmit power generated using RES, particularly from solar generation. Additionally, special incentives and financial aid could be provided to access the schemes effectively. Importantly, awareness and training modules could be provided to attract farmers. Additionally, solar pump sets could be integrated using battery storage, and the additional power could be stored and used for other needs, particularly for lighting at night.

\subsection{Evacuation Infrastructure}

In order to synchronize RESs, a viable channel of transmission is required. Hence, the state should enhance the integration capacity of RESs to the grid by providing better infrastructure support.

\section{Conclusions}

In summary, the demand for energy across the world has been increasing in recent years due to the rapid growth of the population, including in India. This work examined the progress of non-conventional energy in Maharashtra state in detail. Although Maharashtra contributes a considerable RES mix to the total installed capacity, it is far from the targeted capacity and very little compared to net RES potential. Additionally, the contribution of PV generation is not great in the state energy mix, lagging by about four times for the current year and remaining far from the 2022 target. Moreover, the energy demand of the state is directly proportional to population growth, and it should focus on renewable resources that are abundantly available instead of conventional sources. In connection with this, strengths, opportunities, and barriers with regard to the future RES energy mix of the state were explored.

For future sustainable energy development by enhancing the RES mix, government agencies, the research community, and stakeholders may consider the strong suggestions and recommendations proposed in this work to effectively move toward the RES target by 2022.

Author Contributions: Conceptualisation: R.M.E.; Data Curation: R.M.E., L.S., R.R.V., R.S., S.A. and A.H.; Formal Analysis: R.M.E.; Methodology and Research Framework: R.M.E. and R.R.V.; Writing-Original Draft: R.M.E., L.S., R.S. and A.H.; Writing-Revised Draft: R.M.E., K.R. and R.R.V.; Visualisation: R.M.E.; Investigation: R.M.E. and K.R.; Review and Editing: R.M.E., K.R., I.A.K., R.P. and N.D.; Supervision: M.N. and U.S.; Funding Acquisition (towards APC): M.N. All authors have read and agreed to the published version of the manuscript.

Funding: This research activity received no external funding.

Acknowledgments: The authors thank the business society and environmental laboratory, College of Business Administration, Prince Sultan University, Riyadh, Saudi Arabia, for the technical expertise provided. The first author gratefully acknowledges the knowledge of the Renewable Energy framework rendered by G.M. Shafiullah, Discipline of Engineering and Energy, Murdoch University, Perth, Australia, which has helped in the successful development of the research article.

Conflicts of Interest: The authors declare no conflict of interest.

\section{References}

1. Sinsel, S.R.; Riemke, R.L.; Hoffmann, V.H. Challenges and solution technologies for the integration of variable renewable energy sources-a review. Renew. Energy 2020, 145, 2271-2285. [CrossRef]

2. Gielen, D.; Boshell, F.; Saygin, D.; Bazilian, M.D.; Wagner, N.; Gorini, R. The role of renewable energy in the global energy transformation. Energy Strateg. Rev. 2019, 11, 38-50.

3. IRENA and International Energy Agency (IEA). Perspectives for the Energy Transition. Available online: http://www.irena.org/DocumentDownloads/Publications/Perspectives_for_the_Energy_Transition_ 2017.pdf (accessed on 12 January 2020). 
4. IEA \& the World Bank. Sustainable Energy for All-Progress toward Sustainable Energy; The World Bank \& Paris; OECD/IEA: Washington, DC, USA, 2017; Available online: https://www.worldbank.org/content/ dam/Worldbank/Event/Energy\%20and\%20Extractives/Progress\%20Toward\%20Sustainable\%20Energy\% 20-\%20Global\%20Tracking\%20Framework\%202015\%20-\%20Summary\%20Report.pdf (accessed on 20 May 2020).

5. Ministry of Energy and Mineral Resources (MEMR). Available online: https://www.memr.gov.jo/echobusv3. 0/SystemAssets/56dcb683-2146-4dfd-8a15-b0ce6904f501.pdf (accessed on 12 January 2020).

6. Santika, W.G.; Anisuzzaman, M.; Bahri, P.A.; Shafiullah, G.M.; Rupf, G.V.; Urmee, T. From goals tor joules: A quantitative approach of interlinkages between energy and the sustainable development goals. Energy Res. Soc. Sci. 2019, 50, 201-214. [CrossRef]

7. Markard, J.; Raven, R.; Truffer, B. Sustainability transitions: An emerging field of research and its prospects. Res. Policy 2012, 41, 955-967. [CrossRef]

8. Tripathi, L.; Mishra, A.K.; Kumar Dubey, A.; Tripathi, C.B.; Baredar, P. Renewable energy: An overview on its contribution in current energy scenario of India. Renew. Sustain. Energy Rev. 2016, 60, 226-233. [CrossRef]

9. IEA. Renewables Information 2014; International Energy Agency (IEA): Paris, France, 2014; Available online: https://www.iea.org/ (accessed on 20 May 2020).

10. Kim, K.; Park, H.; Kim, H. Real options analysis for renewable energy investment decisions in developing countries. Renew. Sustain. Energy Rev. 2017, 75, 918-926. [CrossRef]

11. Schneider, U.A.; McCarl, B.A. Economic potential of biomass based fuels for greenhouse gas emission mitigation. Environ. Resour. Econ. 2003, 24, 291-312. [CrossRef]

12. Dowaki, K.; Mori, S. Biomass energy used in a saw mill. Appl. Energy 2005, 80, 327-339. [CrossRef]

13. Cicea, C.; Marinescu, C.; Popa, I.; Dobrin, C. Environmental efficiency of investments in renewable energy: Comparative analysis at macroeconomic level. Renew. Sustain. Energy Rev. 2014, 30, 555-564. [CrossRef]

14. Chien, T.; Hu, J.L. Renewable energy and macroeconomic efficiency of OECD and non-OECD economies. Energy Policy 2007, 35, 3606-3615. [CrossRef]

15. Halkos, G.E.; Tzeremes, N.G. Analyzing the Greek renewable energy sector: A data envelopment analysis approach. Renew. Sustain. Energy Rev. 2012, 16, 2884-2893. [CrossRef]

16. Aslani, A.; Antila, E.; Wong, K.F.V. Comparative analysis of energy security in the Nordic countries: The role of renewable energy resources in diversification. J. Renew. Sustain. Energy 2012, 4, 1-12. [CrossRef]

17. Aslani, A.; Naaranoja, M.; Wong, K.F.V. Strategic analysis of diffusion of renewable energy in the Nordic countries. Renew. Sustain. Energy Rev. 2013, 22, 497-505. [CrossRef]

18. European Commission. EU Budget: Commission Proposes Increased Funding to Invest in Connecting Europeans with High-Performance Infrastructure. Available online: http://europa.eu/rapid/press-release_ IP18-4029_en.htm. (accessed on 12 January 2020).

19. Simon, F. EU Strikes Early Morning Deal on Energy Governance Bill, Erective. Available online: https://www. euractiv.com/section/energy/news/eu-strikes-early-morning-deal-on-energy-governance-bill/ (accessed on 12 January 2020).

20. Athienitis, A.K.; Barone, G.; Buonomano, G.; Palombo, A. Assessing active and passive effects of façade building integrated photovoltaics/thermal systems: Dynamic modelling and simulation. Appl. Energy 2018, 209, 355-382. [CrossRef]

21. Huang, J.; Chan, X.; Yang, H.; Zhang, W. Numerical investigation of a novel vacuum photovoltaic curtain wall and integrated optimization of photovoltaic envelope systems. Appl. Energy 2018, 229, 1048-1060. [CrossRef]

22. Rajvikram, M.; Afridhis, S.; Raghavendra Rajan, V.; Umashankar, S.; Nurunnabi, M. SWOT analysis: A framework for comprehensive evaluation of drivers and barriers for renewable energy development in significant countries. Energy Rep. 2020, 6, 1838-1864.

23. Ikrama, M.; Zhanga, Q.; Sroufe, R.; Ali Shah, S.Z. Towards a sustainable environment: The nexus between ISO 14001, renewable energy consumption, access to electricity, agriculture and $\mathrm{CO}_{2}$ emissions in SAARC countries. Sustain. Prod. Consum. 2020, 22, 218-230. [CrossRef]

24. Rajvikram, M.; Shafiullah, G.M.; Manoj Kumar, N.; Sanjeevikumar, P. A State-of-the-Art Review on the Drive of Renewables in Gujarat, State of India: Present Situation, Barriers and Future Initiatives. Energies 2020, 13, $1-30$. 
25. Manoj Kumar, N.; Chopra, S.S.; Chand, A.A.; Rajvikram, M.; Shafiullah, G.M. Hybrid Renewable Energy Microgrid for a Residential Community: A Techno-Economic and Environmental Perspective in the Context of the SDG7. Sustainability 2020, 12, 1-30.

26. Rajvikram, M.; Shafiullah, G.M.; Sanjeevikumar, P.; Manoj Kumar, N.; Annapurna, A.; Ajayragavan, M.V.; Mihet-Popa, L.; Holm-Nielsen, J.B. A Comprehensive Review on Renewable Energy Development, Challenges, and Policies of Leading Indian States with an International Perspective. IEEE Access 2020, 8, 7432-7457.

27. Jeslin Drusila Nesamalar, J.; Venkatesh, P.; Charles Raja, S. The drive of renewable energy in Tamilnadu: Status, barriers and future prospect. Renew. Sustain. Energy Rev. 2017, 73, 115-124. [CrossRef]

28. Rajesh, V.K.; Sanjay, D.P. Electricity demand supply analysis: Current status and future prospects for Maharashtra, India. Renew. Sustain. Energy Rev. 2012, 16, 3960-3966.

29. CFR. Global Climatic Change; Council Foreign Relation (CFR): New York, NY, USA, 2013; Available online: https://www.cfr.org/report/global-climate-change-regime (accessed on 5 May 2019).

30. Kanase-Patil, A.B.; Saini, R.P.; Sharma, M.P. Sizing of integrated renewable energy system based on load profile and reliability index for the state of Uttarakhand in India. Renew. Energy 2011, 36, 2809-2821. [CrossRef]

31. Gupta, A.; Saini, R.P.; Sharma, M.P. Steady-state modelling of hybrid energy system for grid electrification of cluster of villages. Renew. Energy 2010, 35, 520-535. [CrossRef]

32. Rao, N.; Pachauri, S. Energy access and living standards: Some observation on recent trends. Environ. Res. Lett. 2017, 12, 1-5. [CrossRef]

33. Ahmed, S.; Mathai, M.V.; Parayil, G. Household electricity access, availability and human well-being: Evidence from India. Energy Policy 2014, 69, 308-315. [CrossRef]

34. Balachandra, P. Dynamics of rural energy access in India: An assessment. Energy 2011, 36, 5556-5567. [CrossRef]

35. Aklin, M.; Cheng, C.Y.; Urpelainen, J.; Ganesan, K.; Jain, A. Factors affecting household satisfaction with electricity supply in rural India. Nat. Energy 2016, 1, 161-170. [CrossRef]

36. Laha, P.; Chakraborty, B.; Alberg Ostergaard, P. Electricity system scenario development of India with import independence in 2030. Renew. Energy 2019, 11, 1-13. [CrossRef]

37. Bose, A.S.; Sarkar, S. India's e-reverse auctions (2017-2018) for allocating renewable energy capacity: An evaluation. Renew. Sustain. Energy Rev. 2019, 112, 762-774. [CrossRef]

38. Guidelines for Village Electrification through Decentralized Distributed Generation (DDG) under Rajiv Gandhi Grameen Vidyutikaran Yojana in the XI Plan. Available online: https://powermin.nic.in/sites/default/ files/uploads/Guidelines_for_Village_Electrification_DDG_under_RGGVY.pdf (accessed on 5 May 2020).

39. Arunachalam, K.; Pedinti, V.S.; Goel, S. Decentralized distributed generation in India: A review. J. Renew. Sustain. Energy 2016, 8, 1-20. [CrossRef]

40. IEA. Deploying Renewables: Principles for Effective Policies. Available online: http://www.iea.org/ publications/freepublications/publication/DeployingRenewables2008.pdf (accessed on 10 January 2020).

41. IEA. Deploying Renewables: Best and Future Policy Practice. Available online: http://www.iea.org/ publications/freepublications/publication/Deploying_Renewables2011.pdf (accessed on 10 January 2020).

42. Prakash, R.; Bhat, I.K. Energy, economics and environmental impacts of renewable energy systems. Renew. Sustain. Energy Rev. 2009, 13, 2716-2721.

43. Dudhani, S.; Sinha, A.K.; Inamdar, S.S. Renewable energy sources for peak load demand management in India. Int. J. Electr. Power Energy Syst. 2006, 28, 396-400. [CrossRef]

44. Suganthi, L.; Williams, A. Renewable energy in India-a modelling study for 2020-2021. Energy Policy 2000, 28, 1095-1109. [CrossRef]

45. Rajesh Kumar, C.; Majid, M.A. Renewable energy for sustainable development in India: Current status, future prospects, challenges, employment, and investment opportunities. Energy Sustain. Soc. 2020, 2, 1-36.

46. Kumar, N.; Pa1, N. The existence of barriers and proposed recommendations for the development of renewable energy in Indian perspective. Environ. Dev. Sustain. 2018, 22, 2187-2205. [CrossRef]

47. Rani, P.; Raj Mishra, A.; Raj Pardasani, K.; Mardani, A.; Liao, H.; Streimikiene, D. A novel VIKOR approach based on entropy and divergence measures of Pythagorean fuzzy sets to evaluate renewable energy technologies in India. J. Clean. Prod. 2019, 238, 1-17. [CrossRef] 
48. Rani, P.; Raj Mishra, A.; Mardani, A.; Cavallaro, F.; Alrasheedi, M.; Alrashidi, A. A novel approach to extended fuzzy TOPSIS based on new divergence measures for renewable energy sources selection. J. Clean. Prod. 2020, 257, 1-17. [CrossRef]

49. Krishankumar, R.; Raj Mishra, A.; Soundarapandian Ravichandran, K.; Peng, X.; Kazimieras Zavadskas, E.; Cavallaro, F.; Mardani, A. A Group Decision Framework for Renewable Energy Source Selection under Interval-Valued Probabilistic linguistic Term Set. Energies 2020, 13, 986. [CrossRef]

50. Memduh Eren, B.; Taspinar, N.; Gokmenoglu, K.K. The impact of financial development and economic growth on renewable energy consumption: Empirical analysis of India. Sci. Total Environ. 2019, 663, 189-197. [CrossRef]

51. Aandarajah, G.; Gambhfir, A. India's $\mathrm{CO}_{2}$ emission pathways to 2050? Appl. Energy 2014, 131, 68-76.

52. Solar Potential. Available online: http://mnre.gov.in/file-manager/UserFiles/Solar-Potential-NISE.pdf (accessed on 14 January 2020).

53. Akella, A.; Saini, R.; Sharma, M. Social, economical and environmental impacts of renewable energy systems. Renew. Energy 2009, 34, 390-396. [CrossRef]

54. Liserre, M.; Sauter, T.; Hung, J. Future energy systems: Integrating renewable energy sources into the smart power grid through industrial electronics. IEEE Ind. Electron. Mag. 2009, 4, 18-37. [CrossRef]

55. Pedro, R. Dynamic Influences of Wind Power on the Power System. Ph.D. Thesis, Orsted Institute, Electric Power Engineering, Technical University of Denmark, Copenhagen, Danmark, 2003.

56. Shafiulah, G.M. HREI system for subtropical climate in Central Queensland, Australia. Renew. Energy 2016, 96, 1014-1033. [CrossRef]

57. Reda, F.; Viot, M.; Sipila, K.; Helm, M. Energy assessment of solar cooling thermally driven system configurations. Appl. Energy 2016, 166, 27-43. [CrossRef]

58. Seme, S.; Stumberger, G.; Pihler, J. Predicting daily distribution of solar irradiation by neural networks. In Proceedings of the International Conference on Renewable Energies and Power Quality (ICREPQ), Madrid, Spain, 15-17 April 2009.

59. Blenkinsopp, T.; Kirwan, K. Non-conventional energy for rural communities in Maharashtra, India. Energy Policy 2013, 60, 182-187. [CrossRef]

60. Sen, R.; Bhatacharya, S. Off-grid electricity generation with renewable energy technologies in India. Renew. Energy 2014, 62, 388-398. [CrossRef]

61. Azadeh, A.; Maghsoudi, A.; Khani, S. An Integrated Artificial Neural Networks approach for predicting global radiation. Energy Convers Manag. 2009, 50, 1497-1505. [CrossRef]

62. Tahir, Y.; Nadeem, M.F.; Ahmed, A.; Khan, I.A.; Qamar, F. A Review on Hybrid Energy Storage Systems in Microgrids. In Proceedings of the 3rd International Conference on Computing, Mathematics and Engineering Technologies (iCoMET), Sukkur, Pakistan, 29-30 January 2020.

63. Chauhan, A.; Saini, R. Discrete harmony search based size optimization of integrated non-conventional Energy System for remote rural areas of Utarakhand state in India. Renew. Energy 2016, 94, 578-603. [CrossRef]

64. Ramesh, M.; Saini, R.P. Dispatch strategies based performance analysis of a hybrid renewable energy system for aremote rural area in India. J. Clean. Prod. 2020, 259. [CrossRef]

65. Chauhan, A.; Saini, R. Techno-economic feasibility study on integrated non-conventional energy system of India. Renew. Sustain. Energy Rev. 2016, 59, 377-399. [CrossRef]

66. Rajvikram, M. The Motivation for Renewable Energy and its Comparison with Other Energy Sources: A Review. Eur. J. Sustain. Dev. Res. 2018, 3, 1-19.

67. Sana, S.; Syed, S. Review of Spanish renewable energy policy to encourage investment in solar photovoltaic. J. Renew. Sustain. Energy 2012, 4, 1-13.

68. Bebonchu, A.; Chelsea, H. The effect of renewable and non-renewable electricity generation on economic growth. Energy Policy 2018, 112, 111-118.

69. Rajvikram, M.; Gopinath, C.; Ramkumar, S.; Leoponraj, S. A Novel Methodology of IoT Implementation in Energy Management. Power Res. 2018, 14, 85-91. [CrossRef]

70. Wesseh, K.; Boqiang, L. Is renewable energy a model for powering Eastern African countries transition to industrialization and urbanization? Renew. Sustain. Energy Rev. 2017, 75, 909-917. [CrossRef]

71. Taeyoung, J.; Jinsoo, K. What is better for mitigating carbon emissions - Renewable energy or nuclear energy? A panel data analysis. Renew. Sustain. Energy Rev. 2018, 91, 464-471. 
72. Ferda, H.; Natalya, K. Output, renewable and non-renewable energy production, and international trade: Evidence from EU-15 countries. Energy 2018, 159, 995-1002.

73. Hussain, A.; Ali, M.; Tahira, Y. $\mathrm{CO}_{2}$ emissions, energy consumption, economic growth, and financial development in GCC countries: Dynamic simultaneous equation models. Renew. Sustain. Energy Rev. 2017, 70, 117-132.

74. Ting, W.; Boqiang, L. Impacts of unconventional gas development on China's natural gas production and import. Renew. Sustain. Energy Rev. 2014, 39, 546-554.

75. Tasdemiroglu, E. Salt Availability in Turkey and its Potential Use in Solar Ponds. Resour. Conserv. 1987, 15, 215-228. [CrossRef]

76. Hui, X.; Gregory, C.; Berna, K.M. Do non-renewable-Energy prices affect renewable—Energy volatility? The case of wood pellets. J. For. Econ. 2017, 28, 42-48.

77. Kuldeep, H.; Kalpesh, V. Pyramid solar still: A comprehensive review. Renew. Sustain. Energy Rev. 2018, 81, 136-148.

78. Ahmed, A. Wind energy characteristics and wind park installation in Shark El-Quimet, Egypt. Renew. Sustain. Energy Rev. 2018, 82, 734-742. [CrossRef]

79. Ellahi, M.; Abbas, G.; Khan, I.A.; Koola, P.M.; Nasir, M.; Raza, A.; Farooq, U. Recent approaches of forecasting and optimal economic dispatch to overcome intermittency of wind and photovoltaic (PV) systems: A review. Energies 2019, 12, 4392. [CrossRef]

80. Peng, W.; Zeng, Y.; Gong, H.; Leng, Y.Q.; Yan, Y.H.; Hu, W. Evolutionary algorithm and parameters extraction for dye-sensitised solar cells one-diode equivalent circuit model. Micro Nano Lett. 2013, 8, 86-89. [CrossRef]

81. Vega-Garita, V.; De Lucia, D.; Narayan, N.; Ramirez-Elizondo, L.; Bauer, P. PV-battery integrated module as a solution for off-grid applications in the developing world. In Proceedings of the IEEE International Energy Conference (ENERGYCON), Limassol, Cyprus, 3-7 June 2018.

82. Ahmed, A.; Faisal Nadeem, M.; Ali Sajjad, I.; Bo, R.; Khan, I.A.; Raza, A. Probabilistic generation model for optimal allocation of wind DG in distribution systems with time varying load models. Sustain. Energy Grids Netw. 2020, 22, 1-12. [CrossRef]

83. Olumide, O.; Edmund, C. Concentrating solar power technologies for solar thermal grid electricity in Nigeria: A review. Renew. Sustain. Energy Rev. 2018, 90, 104-119.

84. Khalaji, M.; Bakhoda, S.; Saidur, R.; Hanaei, H. Recent progress in perovskite solar cells. Renew. Sustain. Energy Rev. 2018, 81, 2812-2822.

85. Manoharan, P.; Umashankar, S.; Sudhakar Babu, T.; Rajvikram, M.; Mihet-Popa, L. Evaluation of Mathematical Model to Characterize the Performance of Conventional and Hybrid PV Array Topologies under Static and Dynamic. Energies 2020, 13, 1-37.

86. Premkumar, M.; Sowmya, R. An effective maximum power point tracker for partially shaded solar photovoltaic systems. Energy Rep. 2020, 5, 1445-1462. [CrossRef]

87. Premkumar, M.; Babu, T.S.; Umashankar, S.; Sowmya, R. A New Metaphor-less Algorithms for the Photovoltaic Cell Parameter Estimation. Optik 2020, 208. [CrossRef]

88. Rajvikram, M.; Aritra, G.; Tapas, K.; Apoorva, K.; Meenal, S. Investigations on Performance Enhancement Measures of the Bidirectional Converter in PV- Wind Interconnected Microgrid System. Energies 2009, 12, 345-350.

89. Plutshack, V.; Sengupta, S.; Sahayc, A.; Vinnuales, J.E. New and renewable energy social enterprises accessing government support: Findings from India. Energy Policy 2019, 132, 367-378. [CrossRef]

90. Das, M.; Anil Kumar Singh, M.; Biswas, A. Techno-economic optimization of an off-grid hybrid renewable energy system using metaheuristic optimization approaches-Case of a radio transmitter station in India. Energy Convers. Manag. 2019, 185, 339-352. [CrossRef]

91. Rajvikram, M.; Velmurugan, K.; Umashankar, S.; Rakesh Kumar, A.; Almakhles, D. Experimental investigations conducted for the characteristic study of OM29 phase change material and its incorporation in photovoltaic panel. Energies 2020, 13, 1-18.

92. Rajvikram, M.; Leoponraj, S.; Ramkumar, S.; Akshaya, H.; Dheeraj, A. Experimental investigation on the abasement of operating temperature in solar photovoltaic panel using PCM and aluminum. Sol. Energy 2019, 188, 327-338.

93. Rajvikram, M.; Sivasankar, G. Experiment study conducted for the identification of best heat absorption and dissipation methodology in solar photovoltaic panel. Sol. Energy 2019, 193, 283-292. [CrossRef] 
94. Shanmugam, N.; Pugazhendhi, R.; Rajvikram, M.; Kasiviswanathan, P.; Das, N. Anti-Reflective Coating Materials: A Holistic Review from PV Perspective. Energies 2020, 13, 2631. [CrossRef]

95. Rajvikram, M.; Leoponraj, S. A method to attain power optimality and efficiency in solar panel. Beni-Suef Univ. J. Basic Appl. Sci. 2018, 4, 705-708. [CrossRef]

96. Rajvikram, M.; Leoponraj, S.; Rajkumar, S. Enhancement of solar panel efficiency with the adoption of anti reflective coating techniques. J. Sci. Ind. Res. 2020, 79, 261-265.

97. Dong, L.; Ren, J. Spatial distribution of China's non-conventional energy industry. Renew. Sustain. Energy Rev. 2016, 58, 1511-1521.

98. Zhao, Z.; Chang, R. How to stimulate non-conventional energy power generation effectively? Renew. Energy 2016, 92, 147-156. [CrossRef]

99. Saxena, R.; Adhikari, D.; Goyal, H. Biomass based energy fuel through biochemical routes: A review. Renew. Sustain. Energy Rev. 2009, 13, 167-178. [CrossRef]

100. Asalani, A.; Wong, K. Strategic analysis of diffusion of non-conventional energy in the Nordic countries. Renew. Sustain. Energy Rev. 2013, 22, 495-503.

101. Engalken, M.; Wepe, I. Comparing drivers, barriers, and opportunities of business models for non-conventional energies: A review. Renew. Sustain. Energy Rev. 2016, 60, 785-801.

102. Gabriel, C.; Kirkwood, J. Lessons from non-conventional energy entrepreneurs in developing countries. Energy Policy 2016, 95, 326-339. [CrossRef]

103. Ahsan, N. Solid waste management plan for Indian mega cities. Indian J. Env. Prot. 1999, 2, 90-95.

104. Bansal, N.; Srivastava, V.K.; Kheraluwala, J. Renewable Energy in India: Policies to Reduce Greenhouse Gas Emissions. Greenh. Gas Emiss. Energy Environ. Sustain. 2019, 161-178. [CrossRef]

105. Connolly, D.; Matiesen, B. Smart energy Europe: The technical and economic impact of one potential $100 \%$ non-conventional energy scenario. Renew. Sustain. Energy Rev. 2016, 60, 1524-1533. [CrossRef]

106. Alonso, P.; Guilén, J.; Bresers, H. Losing the roadmap: Non-conventional energy paralysis in Spain. Renew. Energy 2016, 89, 670-684. [CrossRef]

107. Galego, C.; Victoria, M. Cost-free feed-in tariffs for non-conventional energy deployment in Spain. Renew. Energy 2015, 81, 401-410.

108. Khan, I.; Xu, Y.; Kar, S.; Chow, M.Y.; Bhattacharjee, V. Compressive Sensing and Morphology Singular Entropy-Based Real-Time Secondary Voltage Control of Multiarea Power Systems. IEEE Trans. Ind. Inform. 2018, 15, 3796-3807. [CrossRef]

109. Haas, R.; Reach, G.; Rawitz, M. Efficiency and effectiveness of promotion systems for electricity generation from non-conventional energy sources. Energy 2011, 36, 2176-2183. [CrossRef]

110. Anwar, J.; Ahmed, S.; Haslenda, H.; Habib, A.; Ramli, M. Economic and environ- mental benefits of landfill gas from municipal solid waste in Malaysia. Renew. Sustain. Energy Rev. 2012, 16, 2907-2912.

111. Zainura, N.; Rafiu, Y.; Ahmad, A.; Mohd, H.; Mohd, F. An overview for energy recovery from municipal solid waste (MSW) in Malaysia scenario. Renew. Sustain. Energy Rev. 2013, 20, 378-384.

112. Shelev, S.; Van, J. Optimal diversity of non-conventional energy alternatives under multiple criteria. Renew. Sustain. Energy Rev. 2016, 60, 659-671.

113. Freaw, B.; Jakobson, M. Flexibility mechanisms and pathways to a highly non-conventional US electricity future. Energy 2016, 101, 45-58.

114. Genzer, E.; Agrawal, R. A commentary on the US policies for efficient large scale non-conventional energy storage systems. Energy Policy 2016, 88, 457-464.

115. Kumar, S.; Malener, R. $\mathrm{CO}_{2}$ emission reduction potential assessment using non-conventional energy in India. Energy 2016, 97, 263-272. [CrossRef]

116. Chadel, S.; Srivastva, R.; Sharma, V.; Ramsamy, P. Overview of the initiatives in non-conventional energy sector under the national action plan on climate change in India. Renew. Sustain. Energy Rev. 2016, 54, 866-873. [CrossRef]

117. Rajvikram, M. Comprehensive Review on India's Growth in Renewable Energy Technologies in Comparison with Other Prominent Renewable Energy Based Countries. J. Sol. Energy Eng. 2020, 142, 03801-03811.

118. Panar, N.; Kauzhik, S. Role of non-conventional energy sources in environmental protection: A review. Renew. Sustain. Energy Rev. 2011, 15, 1503-1514.

119. Christopher, J.; Koroneos, G.; Nanaki, E. Integrated solid waste management and energy production-A lifecycle assessment approach: The case study of the city of Thessaloniki. J. Clean Prod. 2012, 27, 141-150. 
120. Global Renewable Eenergy. Available online: https://www.weforum.org/agenda/2018/02/countrie-behindglobal-renewaable-energy-growth/ (accessed on 4 May 2020).

121. Ministry of New and Renewable Energy Annual Reports. Available online: https://mnre.gov.in/annual-report (accessed on 20 May 2020).

122. India Brand Equity Foundation Renewable Energy in India Report. Available online: https://www.ibef.org/ industry/renewable-energy.aspx (accessed on 20 May 2020).

123. Behuria, P. The politics of late late development in renewable energy sectors: Dependency and contradictory tensions in India's National Solar Mission. World Dev. 2020, 126, 1-12. [CrossRef]

124. Generating Heat Water Through Solar. Available online: https://mnre.gov.in/file-manager/UserFiles/SunFocus_October-December-2016.pdf (accessed on 18 January 2020).

125. Bayrak, F.; Oztop, H.F.; Selimefendigil, F. Effects of different fin parameters on temperature and efficiency for cooling of photovoltaic panels under natural convection. Sol. Energy 2019, 188, 484-494. [CrossRef]

126. Ravindra, K.; Visscher, A.; Dahiya, R.; Chandra, A. Municipal solid waste characterization and its assessment for potential methane generation: A case study. J. Sci. Total Environ. 2006, 1, 1-10.

127. Rajvikram, M. Solutions for voltage SAG in a doubly fed induction generator based wind turbine: A review. Power Res. 2018, 14, 73-77. [CrossRef]

128. Rajvikram, M.; Renuga, P.; Kumar, G.A.; Bavithra, K. Fault ride-through capability of Permanent Magnet Synchronous Generator based Wind Energy Conversion System. Power Res. 2016, 12, 531-538.

129. Rajvikram, M.; Renuga, P.; Swathisriranjani, M. Fuzzy Based MPPT Controller's Role in Extraction of Maximum Power in Wind Energy Conversion System. In Proceedings of the International Conference on Control, Instrumentation, Communication and Computational Technologies (ICCICCT), Kumaracoil, India, 16-17 December 2016.

130. Power supply of Maharashtra. Available online: http://greencleanguide.com/power-supply-position-of-thestate-of-maharashtra/ (accessed on 14 May 2020).

131. Mercindia. Available online: http://www.mercindia.org.in/Aboutus.html (accessed on 20 May 2020).

132. Mahagenco-Solar. Available online: https://www.projectstoday.com/News/MAHAGENCO-may-shift-Sakrisolar-plant-project-to-Vidarbha (accessed on 14 May 2020).

133. Mahatransco. Available online: https://www.mahatransco.in/ (accessed on 24 May 2020).

134. Mahadiscom. Available online: https://www.mahadiscom.in/msedcl-profile/ (accessed on 24 May 2020).

135. Mahagenco. Available online: https://www.mahagenco.in/index.php/about-us/articles (accessed on 20 May 2018).

136. Power Scenario. Available online: http://www.theelectricalguy.in/power-scenario-in-maharashtra-in-detail/ (accessed on 24 May 2020).

137. Ministry of New and Renewable Energy Resources (MNRE)-Solar Parks. Available online: https://mnre.gov. in/img/documents/uploads/bcf7e95e88ae4f8dbfa8bd25d21e5e12.pdf (accessed on 1 May 2020).

138. Solar Power Traffic Signals. Available online: https://www.mahaurja.com/meda/special_projects/solar_ power_traffic_signals (accessed on 1 June 2018).

139. Solar Process Heat Generation. Available online: https://www.mahaurja.com/meda/special_projects/solar_ process_heat_generation (accessed on 1 May 2020).

140. Access for Maharashtra RES. Available online: https://en.wikipedia.org/wiki/Maharashtra (accessed on 5 May 2020).

141. Zerouali, M.; Boutouba, M.; Ougli, A.; Tidhaf, B. Control of variable speed wind energy conversion systems by fuzzy logic and conventional P\&O. In Proceedings of the International Conference on Intelligent Systems and Advanced Computing Sciences (ISACS), Taza, Morocco, 26-27 December 2019.

142. Mohseni, M.; Islam, S.M.; Masoum, M.A.S. Impacts of Symmetrical and Asymmetrical Voltage Sags on DFIG-Based Wind Turbines Considering Phase-Angle Jump, Voltage Recovery, and Sag Parameters. IEEE Trans. Power Electron. 2011, 26, 1587-1598. [CrossRef]

143. Vankusawade Wind Power Plant. Available online: https://www.thewindpower.net/windfarm_en_3330_ vankusawade-wind-park.php (accessed on 14 May 2020).

144. Data System of India. Available online: http://www.india-wris.nrsc.gov.in/wrpinfo/index.php?title=Main Page (accessed on 20 May 2020).

145. Wind Power Technologies. Available online: https:/www.mahaurja.com/meda/grid_connected_power/ wind_power/wind_power_technologies (accessed on 20 May 2020). 
146. Mercindia. Available online: www.mercindia.org (accessed on 24 May 2020).

147. Mahaurja. Available online: www.mahaurja.com (accessed on 24 May 2020).

148. Waste to Energy Mangement. Available online: https://www.mahaurja.com/meda/grid_connected_power/ waste_to_energy (accessed on 4 May 2020).

149. Wind Energy State Policy. Available online: https://www.mahaurja.com/meda/grid_connected_power/wind_ power/state_policy (accessed on 25 May 2020).

150. Solar Power Project. Available online: https://www.mahaurja.com/meda/en/grid_connected_power/solar_ power (accessed on 25 May 2020).

151. Solar Energy State Policy. Available online: https:/www.mahaurja.com/meda/grid_connected_power/solar_ power/state_policy (accessed on 25 May 2020).

152. Biomass Energy State Policy. Available online: https://www.mahaurja.com/meda/grid_connected_power/ biomass/state_policy (accessed on 25 May 2020).

153. Small Hydro Power State Policy. Available online: https://www.mahaurja.com/meda/grid_connected_power/ small_hydro/state_policy (accessed on 5 May 2020).

154. Geothermal Power. Available online: https://www.mahaurja.com/meda/new_technologies/geothermal_ power (accessed on 8 May 2020).

155. Wave Power. Available online: https://www.mahaurja.com/meda/new_technologies/wave_power (accessed on 16 May 2020).

156. Tidal Power. Available online: https://www.mahaurja.com/meda/new_technologies/tidal_power (accessed on 24 January 2020).

157. Farmlands with Solar Power. Available online: https:/energy.economictimes.indiatimes.com/news/ renewable/maharashtra-launches-project-to-connect-farmlands-with-solar-power/61512924 (accessed on 14 May 2020).

158. Floating Solar Power Project. Available online: https:/energy.economictimes.indiatimes.com/news/ renewable/floating-solar-power-projects-maha-mulling-swiss-challenge-method/64535270 (accessed on 18 May 2020).

159. Solar Installation on Ujani Dam. Available online: https://mercomindia.com/maharashtra-study-floatingsolar-ujani-dam/ (accessed on 4 May 2020).

160. Rathi, R.; Prakash, C.; Singh, S.; Krolczyk, G.; Pruncu, C.I. Measurement and analysis of wind energy potential using fuzzy based hybrid MADM approach. Energy Rep. 2020, 6, 228-237. [CrossRef]

161. Chen, W.; Zhang, L. Experimental investigations on the quaternary in- terdiffusion coefficients, Young's modulus and hardness in bcc Ti-Nb-Ta-Zr quaternary alloys. J. Phase Equilib. Diffus. 2019, 40, 1-10. [CrossRef]

162. Fetanat, A.; Khorasaninejad, E.J.O. A novel hybrid MCDM approach for offshore wind farm site selection: A case study of Iran. Ocean Coast. Manag. 2019, 109, 17-28. [CrossRef]

163. Rahman, O.; Muttaqi, K.M.; Sutanto, D. High Temperature Superconducting Devices and Renewable Energy Resources in Future Power Grids: A Case Study. IEEE Trans. Appl. Supercond. 2019, 29, 404-407. [CrossRef]

164. Solar Thermal Policy. Available online: https://www.mahauja.com/meda/data/off_grid_solar/RE\%20Solar\% 20Policies\%20and\%20GRs/Central\%20Policy/Solar\%20Thermal.pdf (accessed on 4 March 2020).

165. Wind Power Policy. Available online: https://www.mahaurja.com/meda/data/off_grid_wind_power/ Telecom\%20Tower\%20Policy.pdf (accessed on 14 April 2020).

166. Wind Power State Policy. Available online: https://www.mahaurja.com/meda/data/grid_wind_power/state_ policy/Policy\%202015_2.pdf (accessed on 14 April 2020).

167. Waste to Energy Policy. Available online: https://www.mahaurja.com/meda/data/off_grid_waste_to_energy/ Waste\%20to\%20Energy\%20-\%20State\%20policy.pdf (accessed on 14 May 2020).

168. Mohammed, Y.; Mokhtar, A.; Bashir, N.; Saidur, R. An overview of agricultural biomass for decentralized rural energy in Ghana. Renew Sustain. Energy Rev. 2013, 20, 15-22. [CrossRef]

169. Shahsavari, A.; Akbari, M. Potential of solar energy in developing countries for reducing energy-related emissions. Renew. Sustain. Energy Rev. 2018, 90, 275-291. [CrossRef]

170. Lupangu, C.; Bansal, R.C. A review of technical issues on the development of solar photovoltaic systems. Renew. Sustain. Energy Rev. 2017, 73, 950-965. [CrossRef]

171. Jain, S.; Jain, N.K.; Vaughn, W.J. Challenges in meeting all of India's electricity from solar: An energetic approach. Renew. Sustain. Energy Rev. 2018, 82, 1006-1013. [CrossRef] 
172. Raina, G.; Sinha, S. Outlook on the Indian scenario of solar energy strategies: Policies and challenges. Energy Strateg. Rev. 2019, 24, 331-341. [CrossRef]

173. Political and Institutional Barriers. Available online: http://www.idfc.com/pdf/publications/Discusion-paperon-Renewable-Energy.pdf (accessed on 4 February 2020).

174. Krishnamoorthy, R.; Udhayakumar, K.; Kannadasan, R.; Rajvikram, M.; Mihet-Popa, L. An Assessment of Onshore and Offshore Wind Energy Potential in India Using Moth Flame Optimization. Energies 2020, 13, 3063.

(C) 2020 by the authors. Licensee MDPI, Basel, Switzerland. This article is an open access article distributed under the terms and conditions of the Creative Commons Attribution (CC BY) license (http://creativecommons.org/licenses/by/4.0/). 